\title{
Review \\ Cellular and Molecular Mechanisms Underlying Liver Fibrosis Regression
}

\author{
Alessandra Caligiuri, Alessandra Gentilini $(D)$, Mirella Pastore, Stefano Gitto $(D)$ and Fabio Marra *(D) \\ Department of Experimental and Clinical Medicine, University of Florence, 50137 Florence, Italy; \\ alessandra.caligiuri@unifi.it (A.C.); alessandra.gentilini@unifi.it (A.G.); mirella.pastore@unifi.it (M.P.); \\ stefano.gitto@unifi.it (S.G.) \\ * Correspondence: fabio.marra@unifi.it
}

Citation: Caligiuri, A.; Gentilini, A.; Pastore, M.; Gitto, S.; Marra, F. Cellular and Molecular Mechanisms Underlying Liver Fibrosis Regression. Cells 2021, 10, 2759. https://doi.org/ 10.3390/cells10102759

Academic Editor: Ralf Weiskirchen

Received: 27 July 2021

Accepted: 9 October 2021

Published: 15 October 2021

Publisher's Note: MDPI stays neutral with regard to jurisdictional claims in published maps and institutional affiliations.

Copyright: (c) 2021 by the authors. Licensee MDPI, Basel, Switzerland. This article is an open access article distributed under the terms and conditions of the Creative Commons Attribution (CC BY) license (https:// creativecommons.org/licenses/by/ $4.0 /)$.
Abstract: Chronic liver injury of different etiologies may result in hepatic fibrosis, a scar formation process consisting in altered deposition of extracellular matrix. Progression of fibrosis can lead to impaired liver architecture and function, resulting in cirrhosis and organ failure. Although fibrosis was previous thought to be an irreversible process, recent evidence convincingly demonstrated resolution of fibrosis in different organs when the cause of injury is removed. In the liver, due to its high regenerative ability, the extent of fibrosis regression and reversion to normal architecture is higher than in other tissues, even in advanced disease. The mechanisms of liver fibrosis resolution can be recapitulated in the following main points: removal of injurious factors causing chronic hepatic damage, elimination, or inactivation of myofibroblasts (through various cell fates, including apoptosis, senescence, and reprogramming), inactivation of inflammatory response and induction of antiinflammatory/restorative pathways, and degradation of extracellular matrix. In this review, we will discuss the major cellular and molecular mechanisms underlying the regression of fibrosis/cirrhosis and the potential therapeutic approaches aimed at reversing the fibrogenic process.

Keywords: liver fibrosis; fibrosis regression; myofibroblasts; HSCs; ECM degradation; therapies

\section{Introduction}

Chronic liver diseases caused by different agents may result in hepatic fibrosis, characterized by a sequence of events leading to excessive deposition of collagen and other extracellular matrix proteins, scar formation and altered liver structure and function, potentially conducting to organ failure in cirrhosis [1,2]. Although in the past years the fibrogenic process was considered a unidirectional and irreversible phenomenon, in the last decades reversal of fibrosis, upon removal of the damaging agent(s), has been described in several tissues. In the liver, due to its regenerative ability, the extent of fibrosis regression and restitution towards normal architecture is higher than in other tissues, even in advanced disease. In recent years, several clinical observations and experimental studies have improved the mechanistic understanding of the fibrogenic process, providing information on the molecular mechanisms underlying reversal of liver fibrosis. Currently, as reviewed in some articles [3-5] the basis of fibrosis resolution can be recapitulated in the following major points:

(1) Interruption or removal of detrimental agent(s) causing chronic hepatic injury [6];

(2) Elimination or inactivation of myofibroblasts [7];

(3) Inactivation of inflammatory response and induction of anti-inflammatory/ "restorative" pathways [8,9];

(4) Degradation of extracellular matrix [10];

The mechanisms underlying the regression of fibrosis are summarized in Figure 1. 


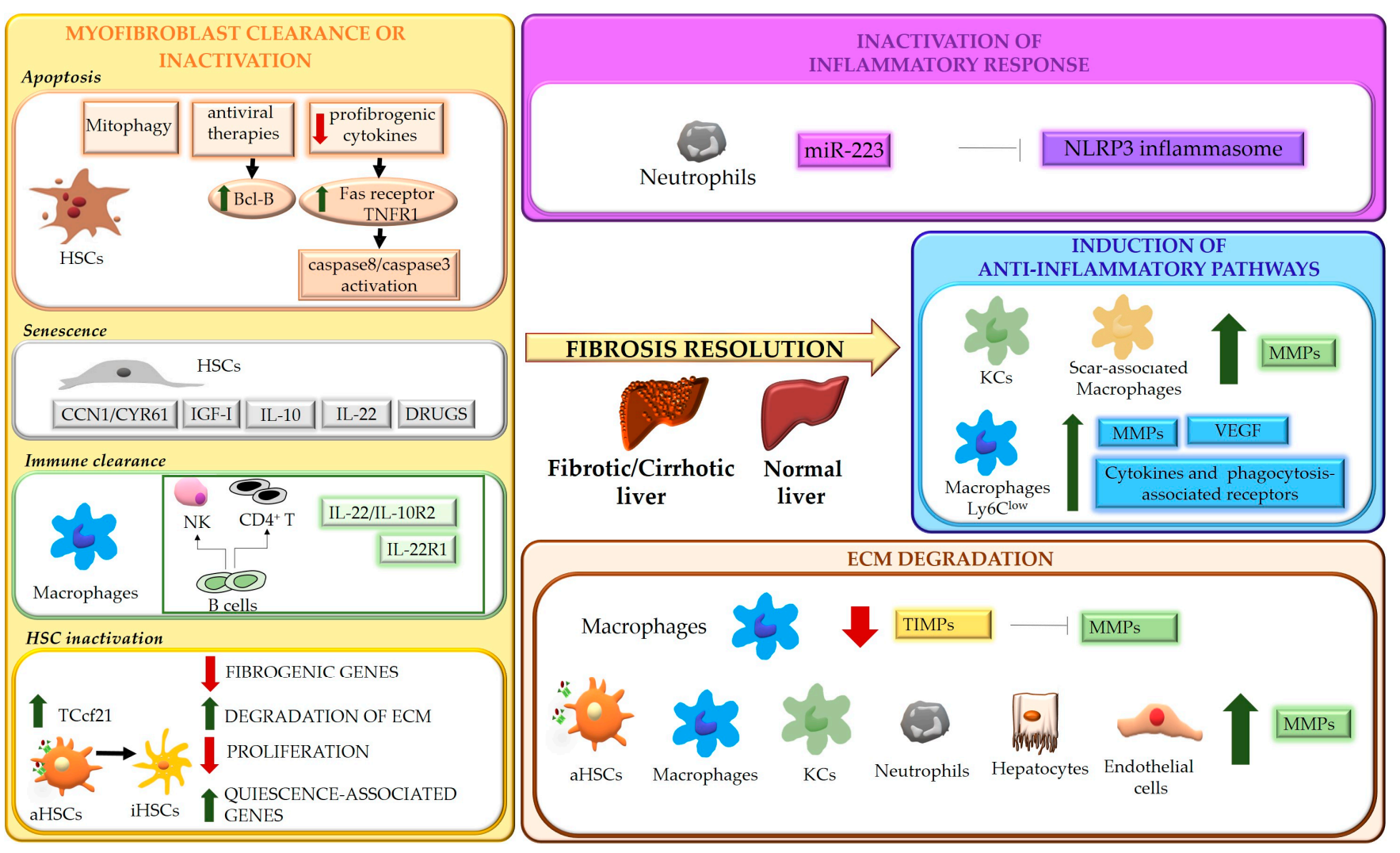

Figure 1. Schematic representation of the mechanisms underlying liver fibrosis regression. Four main mechanisms underlying the regression process of liver fibrosis are indicated. Hepatic stellate cells (HSCs); TNF receptor 1 (TNFR1); insulin-like growth factor I (IGF-I); transcription factor 21 (Tcf21); natural killer cells (NK); activated HSCs (aHSCs); inactivated HSCs (iHSCs); extracellular matrix (ECM); NOD-, LRR- and pyrin domain-containing protein 3 (NLRP3); matrix metalloproteases (MMPs); Kupffer cells (KCs); vascular endothelial growth factor (VEGF); tissue inhibitors of MMPs (TIMPs).

\section{Materials and Methods}

This is a non-systematic review article using the following electronic sources: PubMed, MEDLINE, Google Scholar, Ovid, Scopus, and Web of Science. We used the following single terms "regression of liver fibrosis", "liver fibrotic process regression", "reversibility of cirrhosis", "cellular and molecular mechanisms of fibrosis reversion" or in combination search terms: "regression of fibrosis", "liver", "antifibrotic therapies". We examined all the articles reporting in vitro research, animal models and human related data in English language (inclusion criteria) excluding papers with unavailable full text, abstracts, book chapters and articles published before 1990 (exclusion criteria). Finally, we evaluated supplementary references in papers examined in the first search round.

\section{Removal of Causative Agent(s)}

Clinical evidence has recently demonstrated that compensated cirrhosis caused by chronic HBV or HCV infection is reversible following viral suppression or eradication [11,12]. These findings indicate that removal of the causative agent not only leads to interruption of fibrogenic signals, but also induces fibrolytic/restorative pathways, resulting in regression of fibrosis. However, a certain fraction of patients does not regress, suggesting a potential involvement of genetic/epigenetic mechanisms [13].

In experimental studies performed in mice treated with $\mathrm{CCl}_{4}$ to develop a pre-cirrhotic stage of liver injury and then allowed to spontaneously recover upon toxin withdrawal, resumption of $\mathrm{CCl}_{4}$ exposure rapidly induced profibrogenic features in HSCs, indicating that an "epigenetic memory" can be induced in these and, possibly, other cells [14,15]. 


\section{Genetic/Epigenetic Signatures}

Several genetic diseases predispose to liver fibrosis and in some cases to cirrhosis. These could potentially impair reversal of the fibrogenic process [16]. Many of the genes such as ABCB4, ASL, ALDOB, GBE1, SLC25A13, FAH, and SERPIN1 are highly expressed in the liver and therefore mutations of these genes mainly affect this organ [17]. Most genetic aberrations triggering cirrhosis appear in childhood and are the main cause of pediatric liver cirrhosis, apart from childhood obesity [18]. In addition to the genetic alterations leading to hepatic fibrosis in the childhood, mutations of the PNPLA3 gene represent a major predisposing factor in non-alcoholic fatty liver disease (NAFLD) patients [19]. PNPLA3, encoding for patatin-like phospholipase domain-containing protein 3, is mainly found in hepatocytes, adipocytes, and HSCs. PNPLA3 is endowed with triacylglycerol (TG) lipase and acylglycerol transacylase activities and the TG hydrolase function is reduced by about $\sim 80 \%$ in the presence of the I148M mutation/substitution [20,21]. The PNPLA3 I148M variant has been associated with steatosis, NAFLD, NASH, and hepatocellular carcinoma $[20,22,23]$. The loss of PNPLA3-mediated TG hydrolase activity in this variant is not sufficient to induce hepatic steatosis, since Pnpla3 ${ }^{-/-}$mice did not show fatty liver disease [24]. Therefore, other mechanisms may underlie the development of hepatic steatosis. In mammalian cells, PNPLA3 accumulation in lipid droplets [25-28] is regulated by fasting/feeding cycles, whereas the mutated PNPLA3 (148M) accumulates into lipid droplets evading ubiquitin and/or autophagy protein degradation [29-31]. BasuRay et al. showed that the excess of PNPLA3 into the lipid droplets induce per se fatty liver disease and depletion of the mutant form could resolve the excess of hepatic fat accumulation [30].

HSC contain droplets of retinoic acid, which, by inducing retinoic acid receptor (RAR) expression, inhibits the fibrogenic process [32,33]. It has been observed that PNPLA3 mutations decrease the amount of retinoic acid in HSCs leading to the reduction of RAR-mediated control on fibrogenesis [34]. PNPLA3 might therefore represent a good therapeutic target to control NAFLD-associated fibrosis, steatosis, and disease progression [17]

Epigenetic modifications and changes in expression/activity of epigenetic enzymes regulate many processes involved in fibrosis development, including cell activation, response to injury, and immune reaction. Epigenetic changes, mainly represented by DNA methylation and histone post-translational modifications (mostly methylation and acetylation) act as dynamic modulators of HSCs, repressing or inducing genes and transcription factors implicated in the fibrogenic process, and influencing the response of HSCs to changes in the microenvironment. DNA methylation, as well as changes in methylation enzymes, has been associated with changes in transcription of genes involved in nucleotide metabolism, signaling pathways (e.g., Wnt $[35,36])$, cell proliferation and apoptosis (e.g., Pten [37]), extracellular matrix (ECM) synthesis/degradation (Actg2, Col4A1/2, Loxl1/2, Adamts9, matrix metalloprotease-MMP15 [38]). Of note, altered expression of enzymes that regulate DNA methylation DNA methyltransferases (DMNTs) and ten-eleven translocation methylcytosine dioxygenases (TET) has been observed in fibrotic livers from different animal models and in patients [35,39].

Epigenetic events may serve as adaptive mechanisms. In a pivotal study on multigenerational influences on hepatic fibrogenesis in rats, Zeybel et al. demonstrated that epigenetic adaptation to liver injury could be passed on to F1 and F2 progeny. This adaptation, which consists of a reduced number of myofibroblasts, decreased expression of TGF- $\beta 1$ and increased expression of PPAR- $\gamma$, was mediated by changes in DNA methylation and histone acetylation. Moreover, DNA hypomethylation of the PPAR- $\gamma$ promoter correlated with milder fibrosis in NAFLD patients [40].

A better understanding of the complex epigenetic mechanisms regulating the fibrogenic process could be helpful to identify epigenetic signatures as diagnostic/prognostic markers and to develop novel therapeutic strategies. Selective inhibitors of histone modifying enzymes (histone deacetylases (HDACs) and histone methyltransferases) have been shown to inhibit proliferation and to induce apoptosis in HSCs [41-43], to reduce fibrogenic factors, and to reverse myofibroblast differentiation in various organs [43-48]. 


\section{Myofibroblast Clearance or Inactivation}

The role of activated myofibroblasts in the development of liver fibrosis is well established. Different cell types can contribute to the myofibroblast population, including HSCs, portal fibroblasts, bone marrow-derived collagen producing cells (fibrocytes) and, possibly, parenchymal cells undergoing epithelial-mesenchymal transition (EMT) [49]. Although the origin of activated myofibroblasts may vary depending on the different etiologies of disease [50], HSCs can be considered their major source, as demonstrated by studies showing that HSCs depletion improves fibrosis in models based on both $\mathrm{CCl}_{4}$ intoxication and bile duct ligation [51]. Even in biliary fibrosis, where portal fibroblasts have been suggested to be the primary cell type initiating the fibrogenic response, giving rise to more than $70 \%$ of myofibroblasts, activation of HSCs becomes crucial after the initial phases [50].

During fibrosis regression, in response to a decrease of fibrogenic stimuli, the number of myofibroblasts drops, due to multiple mechanisms, that include restraint of activation, apoptosis, senescence, immune clearance, and reversal to a quiescent-like phenotype [14,15,52-54].

\subsection{Limitation of HSC Activation}

HSC activation is markedly influenced by changes in cellular microenvironment. Apart from soluble mediators, ECM components, matrix stiffness and interactions with neighboring cells, such as injured hepatocytes, immune cells (particularly macrophages), and activated sinusoidal endothelial cells, play an essential role in sustaining HSC/myofibroblast activation [55]. During recovery, changes in the microenvironment consequent to injury cessation contribute to create a milieu unfavorable to HSC activation. Moreover, high levels of intracellular energy are required by HSCs to retain their activated phenotype, and factors interfering with intracellular energy metabolism can hold HSCs in a less secretory and active state [56]. Along these lines, HSCs undergo a metabolic reprogramming during activation, consisting in induction of aerobic glycolysis and reduction of gluconeogenesis and lipogenesis. This metabolic rearrangement, mediated by Hedgehog $(\mathrm{Hh})$ and hypoxiainducible factor (HIF) $1 \alpha$, leads to an accumulation of lactate that further sustains the transactivation process, inducing the expression of proliferative and profibrogenic genes. Interestingly, the amount of stromal glycolytic cells was found to correlate with the severity of liver fibrosis in patients and experimental models. According to these findings, inhibitors of Hh signaling, HIF1 $\alpha$, glycolysis and lactate accumulation could be helpful to limit HSC activation and revert aHSCs to a quiescent state. Costunolide, a natural compound with anti-inflammatory, anti-oxidant and anti-tumor actions [57], has been recently shown to negatively modulate HSC activated phenotype, through inhibition of hexokinase 2, a ratelimiting glycolytic enzyme [58], which maintains glucose inside the cells as a source of energy metabolism [57]. Glutaminolysis is also essential to providing high levels of energy required by HSCs to maintain the activated phenotype [59]. Glutamine synthetase (GS), as well as other enzymes implicated in glutamine metabolism (glutaminase (GLS), aspartate transaminase (AST) and glutamine dehydrogenase (GDH)), was found to be upregulated during HSC activation both in vitro and in experimental fibrosis [59]. Accordingly, the expression of GLS, GDH1, AST1 and AST2 genes was significantly enhanced in the liver of fibrotic patients [60]. Hh and its downstream effectors, as Hippo, Yes-associated protein (YAP) and transcriptional co-activator with PDZ-binding motif (TAZ), are crucial for the increase in glutamine metabolism, as demonstrated by the fact that blocking Hh cascade with specific inhibitors (cyclopamine or verteporfin) reduced glutaminolysis, mitochondrial respiration, cell proliferation and collagen synthesis in HSCs [61].

\subsection{Apoptosis}

Apoptosis, a form of programmed cell death, regulates the balance of proliferating and dying HSCs during the fibrogenic process. This phenomenon contributes to reduce the amount of myofibroblasts but is not sufficient to restore the integrity of the liver tissue.

Clearance of HSCs is induced by the cytotoxic action of natural killer (NK) cells after the removal of the injurious agent [62], due to the increase of ligands of NK receptors 
such as MICA, NKG2D, and ULBP2 in senescent aHSCs. Moreover, during fibrosis resolution, increased collagen degradation by MMPs induces HSC apoptosis by activation of death receptor-mediated signaling, including Fas and TNFR-1 receptors, increase in pro-apoptotic proteins (e.g., p53, Bax, caspase 9), and decrease of anti-apoptotic proteins, including Bcl-2 [63,64].

In addition, in response to reduced levels of profibrogenic factors, the expression of Fas or TNFR1 and of the cognate ligands increases in HSCs, stimulating caspase 8/caspase 3 activation and apoptosis [62]. Tumor necrosis factor-related apoptosis inducing ligand (TRAIL) has been recently identified as an additional inducer of apoptosis in HSCs, both in experimental fibrosis [65] and in vitro [66], and its effect involves NF- $\mathrm{kB}$ and miR145 [67]. Additional mechanisms of programmed cell death in aHSCs are mediated by cyclooxygenase-2 (COX-2), which metabolizes the endogenous cannabinoid 2-arachidonoyl glycerol (2-AG) leading to the production of the pro-apoptotic prostaglandin D2-glycerol ester (PGD2-GE) [68]. On the other hand, caspase-9-dependent apoptotic pathways are elicited by increased expression of Bcl-2, Bax and p53 [62]. A recent report showed that mitophagy, a mechanism that eliminates damaged mitochondria to maintain mitochondrial homeostasis, is increased in HSCs during the regression of fibrosis, in parallel with enhanced apoptosis. Mitophagy contributes to apoptosis inducing an increase in Bcl-B, a member of the Bcl-2 family [69].

\subsection{Senescence}

Senescence is a passive and irreversible mechanism of cell death contributing to myofibroblast clearance during fibrosis regression [52]. Senescent cells stop proliferating due to cell-cycle arrest associated with telomere shortening [52] or other alterations, including chromatin modifications [70], DNA damage [70], oncogene activation, loss of tumor suppressors [70] and cellular stress, such as abnormal nutrient $/ \mathrm{O}_{2}$ levels, altered ECM, oxidative stress [70-72]. Through a senescence-associated secretory phenotype (SASP), senescent myofibroblasts promote reversal of fibrosis preventing further proliferation of fibrogenic cells, upregulating ECM-degrading enzymes, and downregulating ECM proteins, including collagens [73]. Recruitment and function of immune cells involved in the clearance of activated HSCs, such as NK cells, is also involved in this process [52]. A variety of proteins, such as the matricellular protein CCN1/CYR61 [74], insulin-like growth factor I (IGF-I) and interleukin (IL)-10, IL-22 have been identified as inducers of senescence in aHSCs. This process is also stimulated by different drugs $[75,76]$, such as the celecoxib derivative, OSU-03012 [77], nuclear receptor agonists (PPAR $\gamma$, RAR and retinoic $\mathrm{X}$ receptor (RXR)) [70], or phytochemicals as curcumin, which promotes HSC senescence via PPAR $\gamma /$ p53 [78]. Soluble egg antigens (SEA) of schistosoma japonicum were also reported to induce senescence in activated HSCs via FoxO3a/SKP2/p27 [77].

\subsection{Immune Clearance}

Clearance of myofibroblasts is also triggered by the immune system. Besides macrophages, that can promote aHSC apoptosis [79], activated NK and liver-specific natural killer T cells induce rapid killing of HSCs, secreting a wide range of cytokines [80-82].

Both senescent and activated, but not quiescent, HSCs can be eliminated by NK cells through retinoic acid early inducible 1/natural killer group 2 member D (NKG2D)dependent and TRAIL-dependent pathways [81], whereas NKT cells selectively target activated HSCs by release of IL-30 [83] and IFN- $\gamma$ [84]. Li et al. recently showed that activated NK cells require the p38/PI3K/Akt pathways to promote TRAIL-induced cytolytic effects on aHSCs [85]. NK cells also induce HSC apoptosis through FasL [84], due to high Fas expression in aHSCs, and TRAIL [86], and restrain HSC activation via IFN $\gamma$ release [87]. Of note, as the fibrogenic process progress, NK cell activation tends to diminish, impairing the protective function of this system [88].

$\mathrm{CD}^{+} \mathrm{T}$ (Th1, Th2, Th17) and regulatory T cells (Treg) are major modulators of immune response, with direct or indirect effects on fibrosis regression [89]. Activated T lymphocytes 
were reported to induce aHSC senescence through IL-22/IL-10R2 and IL-22R1 [90]. $\gamma \delta \mathrm{T}$ cells, that represent $3-5 \%$ of liver lymphocytes, were recently shown to promote fibrosis regression. Using a $\mathrm{CCl}_{4}$-induced model of fibrosis in $\gamma \delta \mathrm{T}$ cell-deficient mice, Liu et al. demonstrated that these cells suppress liver fibrosis by at least two mechanisms, a direct cytotoxic effect on aHSCs, triggered by NKp46, and an indirect action, involving the crosstalk with NK cells. The IFN- $\gamma$ releasing subset $(\gamma \delta \mathrm{T} 1)$ was found to be more active against aHSCs than the IL-17 secreting subtype ( $\gamma \delta$ T17) [91].

The role of B lymphocytes in hepatic fibrogenesis is mediated by direct or indirect actions on different cell types, including HSCs, NK cells or $\mathrm{CD}^{+} \mathrm{T}$ lymphocytes [83]. Faggioli et al. showed that in a mouse model of chronic fibrosing cholangitis, ablation of $B$ lymphocytes and consequent downregulation of the TNF- $\alpha / N F-\kappa B$ pathway suppresses HSC activation and induces HSC senescence [92].

\subsection{HSC Inactivation}

Development of promoters selectively driving transgenes in HSCs, to achieve cellspecific gene expression, revealed that aHSCs can revert to an inactive/quiescent-like phenotype during regression of liver fibrosis $[14,15]$. In an elegant study performed using the Cre-LoxP-based genetic labeling technique, Kisseleva et al. investigated the fate of HSCs in alcohol- or $\mathrm{CCl}_{4}$-induced experimental fibrosis. During recovery from fibrosis, about $50 \%$ of hepatic myofibroblasts escape apoptosis and revert to a quiescent-like phenotype, downregulating fibrogenic genes and upregulating the survival factors Hspa1a/b [14]. An interesting study by Song et al. showed that upon ectopic expression of the transcription factors FOXA3, GATA4, HNF1A, and HNF4A, mouse myofibroblasts transdifferentiate into hepatocyte-like cells. The transcriptional reprogramming was achieved both in vitro and in vivo, in fibrotic mice, resulting in amelioration of liver fibrosis [93]. Recently, transcription factor 21 (Tcf21) has also been identified as a deactivation factor for myofibroblastic HSCs. TCcf21 levels decrease during the fibrogenic process both in humans and mice and return to normal levels upon regression of murine fibrosis. TCf21- overexpressing aHSCs reverted to a quiescent phenotype with consequent regression of fibrosis and amelioration of hepatic structure and function. Of note, HSCs overexpressing TCf21 failed to store vitamin A, indicating that this transcription factor is unable to modulate the whole program of HSC deactivation [94].

The above findings are in agreement with in vitro studies showing that aHSCs can revert to a quiescent-like status, acquiring a novel phenotype, similar but distinct from the original quiescent cells, and characterized by low proliferation rate and elevated metalloproteinase activity $[95,96]$. Gene expression analysis revealed that inactivated (i) HSCs display reduced levels of fibrogenic genes such as collagens, LOX and $\alpha$-smooth muscle actin ( $\alpha$-SMA), and increased expression of adipogenic, quiescence-associated genes, such as PPAR $\gamma$. Of note, the expression of glial fibrillary acidic protein, adiponectin receptor1, Adpf, and D site of albumin promoter binding protein, typical of the quiescent status of HSCs, remain absent [96]. Functionally, iHSCs are more sensitive to fibrogenic stimuli and rapidly reacquire profibrogenic features [14]. Interestingly, in vitro studies performed on a gradually softening hydrogel mimicking microenvironmental changes occurring during fibrosis progression and regression, proved that mechanical stimuli are crucial for activation and reversion of HSCs [97]. Accordingly, a recent study by Dou et al. showed that substrate stiffness in vitro or liver stiffness in vivo induced posttranslational changes in histones, transcription factors and coactivators in HSCs, leading to their activation. These events were mediated by the histone acetyltranferase p300. Indeed, stiffness induced, via RhoA/Akt, the phosphorylation and nuclear translocation of p300, resulting in transcription of several genes associated with the HSC profibrogenic phenotype, as $\alpha$-SMA, CTGF, PDGFA and B, VEGFA, IL-11, IL-6, CXCL12 [98]. From a translational point of view, these findings suggest the possibility to induce fibrosis regression by affecting specific signals that trigger this response [99]. 


\section{Modulation of Inflammatory Processes}

Inflammation represents a main feature of chronic liver diseases and plays a key role in any stages of the fibrogenic process, even during fibrosis regression. Inflammatory response involves multicellular interactions, dynamically regulated by a plethora of factors (e.g., soluble mediators, ECM components, pathogen-associated molecular patterns-PAMPs, damage-associated molecular patterns-DAMPs), acting in cell-specific fashion and aimed to restore liver architecture and function, but also leading to liver fibrosis when the noxious agent persists.

Cell death is an early and primary inducer of chronic inflammation and fibrosis. Hepatocyte-derived apoptotic bodies stimulate the secretion of pro-inflammatory and profibrogenic cytokines from macrophages and promote activation of HSCs through induction of autophagy [100-102]. In addition, injured hepatocytes release DAMPs, such as ATP, phormyl peptides, High Mobility Group Box 1(HMGB1) [103] and cytokines such as IL-33 [104], which triggers HSC activation directly or indirectly, by promoting IL-13 release by innate lymphoid cells (ILC2). At the same time, inflammatory mediators secreted by infiltrating immune cells contribute to cell death, amplifying hepatic injury [104].

As major effectors of fibrosis, activated HSCs play a central role in inflammation, receiving a wide variety of stimuli from inflammatory cells and from hepatocytes, cholangiocytes and activated sinusoidal endothelial cells (SECs). Activated HSCs are highly responsive to inflammatory mediators which induce inflammatory pathways (such as NF-KB and AP-1) $[105,106]$ and consequent secretion of cytokine/chemokines that act in autocrine and paracrine fashion. Inflammatory signals exert specific roles on HSCs, maintaining survival (IL-1 $\beta$, TNF $\alpha$, CXCL12) and the activated state (ILs and chemokines) [107], providing chemotactic stimuli for HSCs themselves or inflammatory cells (CCL2, CCL5, CXCL9, CXCL10, CX3CL1) and mediating the gut-liver axis crosstalk (toll like receptors (TLRs)) [105]. All these processes can contribute to positively or negatively modulate inflammatory responses and fibrogenesis, promoting fibrosis progression or regression.

As modulators of liver fibrosis, immune cells exhibit a dual role, being able to contribute to both fibrosis progression and regression $[108,109]$. Danger signals generated in the site of injury lead to infiltration of circulating inflammatory cells (T lymphocytes, neutrophils, dendritic cells and monocytes) and activation of Kupffer cells (KCs) [108,109]. The release of a wide range of soluble mediators amplifies inflammation and stimulates the fibrogenic process. Upon removal of the cause of injury, the balance switches from pro- to anti-inflammatory/restorative pathways, promoting fibrosis resolution. This shift is achieved by rearrangements in the type of immune cell populations recruited, with a marked drop in intrahepatic T cells and blood-derived cells (NKT cells, monocytes) [110], and phenotypic modifications of certain cell types, mainly macrophages.

\subsection{Neutrophils}

Neutrophils have been recently shown to play an important role in the resolution of the inflammatory response in various tissues [111-113]. Mice with neutrophil depletion during the recovery phase of liver inflammation showed impaired hepatic fibrosis and altered liver architecture. A similar outcome was observed in mice with deletion of the granulocyte-specific miR-223 gene, a negative post-transcriptional regulator of NLRP3 inflammasome. A complete recovery of liver function could be achieved restoring miR-223 levels or with adoptive transfer of wild-type neutrophils. These findings indicate a potential restorative phenotype of neutrophils expressing miR-223, able to promote the resolution of the inflammatory process [114]. High polymorphonuclear (PMN) cell infiltration in liver biopsies of patients with alcoholic hepatitis has been associated with better prognosis, further supporting a regenerative function of neutrophils, and suggesting that sustaining liver regeneration could be more appropriate than inhibiting the inflammatory process [115]. 


\subsection{Macrophages}

Hepatic macrophages derive from both circulating monocytes, recruited to the injured liver via growth factors and chemokine signals, or from self-renewing embryo-derived resident macrophages, called KCs [116]. Macrophages are a highly plastic and heterogeneous population with multiple functions, according to injury kinetics and environmental settings. Recent reports on single-cell mRNA sequencing of liver cell populations highlighted the heterogeneity and plasticity of the macrophage compartment in both rodent models and human disease [116-118]. Macrophage heterogeneity and plasticity are characterized by different cell surface markers and transcriptional profiles, and different stimuli can induce the polarization of macrophages [119]. In most cases, a classification in two main subsets: M1 (classically activated) and M2 (alternatively activated) is widely used [120].

Classically activated macrophages differentiate into M1 macrophages producing proinflammatory cytokines such as IL-6, TNF-a, IL-1, IL-12, IL-15, and IL-18 [121], whereas alternatively activated macrophages modulate inflammatory reactions and mediate tissue repair. Alternatively activated macrophages can be further distinguished in diverse subtypes, each induced by different molecules and eliciting different signals. In particular, M2a macrophages are stimulated by IL-4 and IL-13, and mainly induce a Th2 response. M2b macrophages are stimulated by immune complexes and are involved in Th2 activation and immune regulation, and M2c macrophages are stimulated by IL-10 or TGF- $\beta$ and are involved in immune suppression, tissue repair and matrix remodeling [119]. However, this traditionally classification based on induction of in vitro polarization does not well describe the phenotypic heterogeneity of hepatic macrophage in vivo [109]. In murine models, Ly6c expression is used to characterize populations of circulating monocytes and macrophages in pathology $[119,122]$. Circulating $\mathrm{Ly}^{6} \mathrm{c}^{+} /$high and Ly $6 \mathrm{c}^{-} /$low monocytes have been well characterized. Their counterparts in humans are classically activated $\left(\mathrm{CD} 14^{+} \mathrm{CD} 16^{+}\right)$monocytes expressing CCR2, CD64, and selectin L and non-classical $\left(\mathrm{CD} 14^{+} \mathrm{CD} 16^{-}\right)$monocytes which do not express CCR2, respectively [123]. Ly6c high monocytes are considered precursors to Ly6 $\mathrm{c}^{\text {high }}$ and Ly6c ${ }^{\text {low }}$ macrophages. Ly $6 \mathrm{c}^{\text {high }}$ mirror M1 macrophages exhibiting pro-inflammatory phenotype, while Ly6clow macrophages exhibit an M2-like phenotype that play an anti-inflammatory role during liver damage [124].

In the healthy liver the number of KCs remains constant, and they are the predominant macrophage population in the liver; following liver damage the intrahepatic macrophages are massively expanded, due to the influx of peripheral monocytes [125].

\subsubsection{Embryologically-Derived/Resident Macrophages}

KCs express specific markers useful for their characterization, such as $\mathrm{F} 4 / 80, \mathrm{CD} 11 \mathrm{~b}^{+/ \mathrm{low}}$, CD68 and, C-type lectin domain family 4 member F (CLEC4F) in mice [122]. In the early stages of liver damage, KCs exert proinflammatory and protective actions, through the release of cytokines and chemokines, which further recruit other immune cells. Simultaneously, KCs play a relevant role in the fibrogenic process, via TGF- $\beta$ and PDGF-mediated activation of HSCs [81]. After removal of injury, hepatic macrophages contribute to fibrosis resolution by secreting MMPs $[15,95]$. In addition, they also interact with NKT cells that, as reported above, contribute to aHSC elimination [81].

\subsubsection{Bone-Marrow/Monocyte-Derived Macrophages}

During injury, activated KCs and HSCs induce the recruitment of Ly6C hi expressing monocytes, which rapidly convert to Ly6 $\mathrm{C}^{\text {hi }}$ macrophages characterized by high phagocytic activity [126], through CCL2/CCR2 and other chemokine systems. These cells can secrete a variety of mediators (e.g., TNF, IL-6, IL- $1 \beta$ or TGF- $\beta$ ) that can act in a proinflammatory or anti-inflammatory/profibrogenic fashion, depending on the timing of release and the immune/ECM microenvironment $[79,124]$.

During fibrosis regression, macrophages undergo phenotypic conversion to a restorative Ly6C low subset, able to secrete MMPs like MMP9 and MMP12, growth factors such as VEGF and cytokines, and express phagocytosis-associated receptors [124]. This shift is 
induced by phagocytosis of apoptotic myofibroblasts and/or injured hepatocytes and is mediated by the fractalkine receptor CX3CR1 [127]. As mentioned above, MMPs secreted by restorative macrophages may vary during the regression process, being influenced by soluble mediators released in the milieu. Thus, VEGF-induced CXCL9 release in macrophages results in MMP13 secretion [128], whereas the IL-4/IL-13/IL-4R $\alpha$ axis mainly stimulates MMP2, through STAT6 [129]. Interestingly, IL-4R $\alpha$ is a key player in macrophage polarization toward the anti-inflammatory/restorative M2 phenotype but is also involved in hepatic inflammation and fibrosis during the fibrogenic process [129].

In cirrhotic patients, [130], Cardoso et al. observed an increase in circulating intermediate monocytes $\left(\mathrm{CD} 14^{+} \mathrm{CD} 16^{+}\right)$, distinguished from the classical monocytes $\left(\mathrm{CD} 14^{++}\right.$ $\left.\mathrm{CD}^{-} 6^{-}\right)$and from nonclassical monocytes $\left(\mathrm{CD} 14^{-/ \text {low }} \mathrm{CD}^{+} 6^{+}\right.$[131]. They detected alterations in the proportions of circulating monocytes, particularly in patients with more advanced liver disease. Moreover, the cytokine profile analyzed in this study showed elevated plasma levels of IL-6 and IL-10, particularly in patients with acute decompensation of cirrhosis. Taken together, these findings indicate in cirrhosis the presence of systemic effects that influence the immune-hematopoietic system. Interestingly, a distinct population of scar-associated macrophages deriving from recruitment and differentiation of circulating monocytes has been identified, following liver damage. This macrophage subtype has an important role in resolution of liver fibrosis, representing one of the sources of MMP13 in fibrotic niches in livers of cirrhotic patients [132]. During the early stages of liver injury, scar-associated macrophages differentiate into inflammatory macrophages, and subsequently switch to an anti-inflammatory phenotype, which secretes a wide variety of MMPs to facilitate fibrosis resolution $[133,134]$.

\section{ECM Degradation}

Liver fibrosis is a dynamic process characterized by an unfavorable balance between ECM deposition and degradation. Degradation of ECM represents one of the most relevant aspects of fibrosis regression and requires activation of MMPs, macrophage phagocytic activity and downregulation of MMP-inhibitory molecules, such as tissue inhibitors of MMPs, TIMPs [7,10]. MMPs are the main matrix-degrading enzymes [62] and, according to substrate specificity, can be grouped in collagenases (MMP8, MMP1 and MMP13) which cleave native fibrillar collagens to gelatin, gelatinases (MMP2, MMP9), degrading a wide range of substrates including gelatin, collagens and, in some extent, elastin, metalloelastases (MMP12) and others (Table 1).

Table 1. Classification of human metalloproteinases (MMPs) and their function.

\begin{tabular}{ccc}
\hline MMPs & GROUP & FUNCTION \\
\hline MMP1, MMP8, MMP13 & Collagenases & $\begin{array}{c}\text { Cleavage of native fibrillar } \\
\text { collagens to gelatin }\end{array}$ \\
\hline MMP2, MMP9 & Gelatinases & $\begin{array}{c}\text { Degradation of a wide range } \\
\text { of substrates, including } \\
\text { gelatin, collagens and elastin }\end{array}$ \\
\hline MMP12 & Metalloelastases & Elastin degradation \\
\hline
\end{tabular}

They are secreted by various cell types, including aHSCs, hepatocytes, endothelial cells, and inflammatory cells, such as neutrophils and macrophages. MMP release and activity are finely regulated during the different phases of fibrogenic process, as well as during fibrosis regression. In this context, a relevant role in matrix degradation is played by "restorative" macrophages that, besides a role in phagocytic digestion of matrix fragments, represent a major source of MMP12, MMP13, and MMP9 [124]. In a recent study, Feng et al. showed that in thioacetamide (TAA)-induced fibrosis, depletion of KCs delayed resolution following toxin withdrawal and this was mainly ascribed to a marked decrease in MMP9 [135]. Because activated HSCs display high TIMP levels, ECM degradation 
strictly correlates with HSC clearance and the subsequent shift in MMPs/TIMPs balance, creating the conditions for a milieu favoring parenchymal regeneration.

\section{Reversibility of Cirrhosis}

ECM remodeling is crucial in determining reversibility of fibrosis. In recent years, clinical and experimental studies have provided evidence that matrix remodeling and at least partial restitution towards a normal architecture may be observed even in advanced liver fibrosis or cirrhosis [136-140]. The amount of elastin and cross-linked proteins in fibrotic scars is critical in this process. Protein cross-linking, which is mediated by cellular transglutaminases and lysyl oxidases, stabilizes ECM, enhancing its resistance to enzyme degradation and, together with elastin, increases matrix stiffness, that further sustains HSC activation via integrin-mediated mechanisms [62]. In this setting, MMP12 released by macrophages can still promote matrix turnover acting not only on elastin but also on collagens [141]. However, ECM remodeling in cirrhotic scars is also influenced by vascular remodeling that can hamper matrix degradation [142]. Thus, even when restitution to normal liver architecture is achieved, cirrhosis-associated derangements in the vascular system and in other organs persist. By using two different models of cirrhosis induction and reversal (TAA and BDL), Hsu et al. demonstrated that, despite a complete regression of fibrotic scars, portal hypertension was only partially reduced, due to persisting alterations in splanchnic and collateral circulation [143].

These biologic considerations have clear clinical implications. Regression of fibrosis represents a major clinical goal, since it can lead to a recovery of liver function and reduction in portal pressure, which decrease the incidence of portal-hypertensive complications and of hepatocellular carcinoma (HCC) [144-147]. It is well known that mild and moderate fibrosis can be reversible, but the same concept is not always true for cirrhosis. In this respect, the identification of a "point of no return" in the natural history of liver disease can be very difficult, despite its utmost relevance in clinical practice. This may be viewed as a condition beyond which even causal therapy (e.g., viral eradication) does not determine a significant regression of fibrosis and/or has limited impact on the appearance of complications and prognosis of the patient. As indicated above, the degree and amount of structural damage, in particular the development of extensive matrix crosslinking [148] and accumulation of elastin fibers in long-standing cirrhosis, have been indicated as a major element to identify the "point of no return" [141].

From a clinical standpoint, the 'model' of HCV eradication has provided relevant data in this context. Patients with compensated cirrhosis (Child-Turcotte-Pugh class A) achieving viral eradication with direct-acting antivirals (DAAs), show regression of fibrosis in a relevant percentage of cases (88\%) [149] and a consequent decrease of portal hypertension [150]. When patients with cirrhosis Child-Pugh class B and C are considered, long-term data about the effects of sustained virologic response (SVR) after DAA treatment on fibrosis and liver-related complications and survival are less abundant. However, data from other contexts (e.g., HBV or alcohol-related decompensated cirrhosis) indicated that Child C class could represent a "point of no return" in terms of fibrosis decrease even after removal of the etiologic factor [151,152]. Other clinical predictors of the lack of fibrosis regression include age ( $>65$ years), albumin $(<3.5 \mathrm{~g} / \mathrm{dL})$, high MELD score $(>20)$, alcohol habit and presence of metabolic disorders. However, none of them are satisfactory consistent to be used in clinical practice [153].

Advanced liver fibrosis and cirrhosis are major risk factors for HCC [154,155]. In particular, fibrosis and cancer-associated fibroblasts (CAF,) can influence the onset of HCC modulating the cancer microenvironment $[156,157]$. Considering these assumptions, HCV eradication should determine a decrease of both HCC occurrence and recurrence. In recent years, this has been a very debated issue since some studies suggested that SVR due to DAA, differently from interferon-based therapies, could increase the risk of both occurrence and recurrence of liver cancer [158]. It is now accepted that there is no such risk on a population basis and, as recently demonstrated [159], SVR due to DAAs leads 
to a drop in all-cause mortality, hepatic decompensation, and HCC. Nevertheless, on an individual basis, DAAs might favor the HCC development in subjects who already have a predisposing hepatic condition such as activated neo angiogenesis [160]. Moreover, subjects with severe metabolic impairment may have a risk of HCC despite viral eradication [161]. DAA-induced modifications in VEGF, epidermal growth factor, and inflammatory factors have been proposed for the detection of subgroups at risk of HCC, and some authors have proposed these as possible determinants of the susceptibility to cancer development [162,163].

\section{Vascular Remodeling}

As anticipated above, angiogenesis and vascular remodeling represent additional mechanisms involved in both fibrosis development and regression. Although the role of angiogenesis in promoting liver fibrosis is fully accepted, new lines of evidence indicate that angiogenic factors may also induce scar degradation and tissue repair during fibrosis resolution. Using murine models of fibrosis reversal, Yang et al. showed that the VEGF/VEGFR2 pathway is essential to maintaining sinusoidal permeability and the subsequent monocyte infiltration and macrophage fibrinolytic activity [128]. Moreover, VEGF release by macrophages was shown to be critical for fibrosis resolution. In fact, VEGR2-mediated activation by VEGF induced ECM degradation through upregulation of MMPs and downregulation of TIMPs in sinusoidal endothelial cells [164].

Capillarization of the sinusoids and changes in liver sinusoidal endothelial cells (LSECs) represent key events in liver fibrogenesis, triggering HSC activation and impairing hepatocyte polarization. These consist in LSEC dedifferentiation with loss of fenestrae and deposition of a continuous basement membrane that hampers normal exchanges between blood circulation and hepatocytes. Restoration of differentiated LSEC is crucial for recovery from hepatic fibrosis, as proved by the fact that depleting factors implicated in sinusoidal permeability, such as VEGF or CXCL9, results in delayed recovery [128]. In a thioacetamide-induced rat model of cirrhosis, administration of BAY 60-2770, an activator of soluble guanylate cyclase (sGC), promoted a complete reversal of sinusoid capillarization, by restoring normal levels of CGMP, fenestrae, and porosity in LSECs. Restitution to differentiated LSECs resulted in reversal of HSC activation and regression of fibrosis. Moreover, maintenance of physiological levels of cGMP in LSECs was essential to prevent fibrosis progression [165]. Liver X Receptor (LXR) $\alpha$, which mediates multiple antifibrogenic actions interfering with the activation of HSCs, the release of inflammatory mediators and the synthesis of profibrogenic factors [56,166-168], was hypothesized to play a role in reverting capillarization of the sinusoids, through inhibition of Hedgehog-dependent signaling in LSECs [169]. In a mouse model of biliary fibrosis induction and reversal, Lee et al. identified AKAP12, a scaffold protein expressed in various cell types regulating cyclic adenosine monophosphate (cAMP) compartmentalization, as a novel mediator of fibrosis resolution, through mechanisms affecting LSEC dedifferentiation/activation and angiogenesis [170]. In an elegant study, $\mathrm{Xu}$ et al. identified leukocyte cell-derived chemotaxin 2 (LECT2) as a ligand of Tie1 (an orphan receptor expressed by endothelial cells) and LECT2-Tie1 as a novel profibrogenic pathway involved in vascular remodeling, that enhances sinusoid capillarization and reduces portal angiogenesis. They showed that knockdown of LECT2 (in both LECT2 KO mice and AAV9-LECT2 shRNA- treated mice) attenuates fibrosis development and ameliorates established fibrosis in different experimental models, reducing sinusoid capillarization and increasing portal angiogenesis. Notably, serum levels of LECT2 were significantly increased in patients with advanced fibrosis, indicating LECT2-Tie1 signaling as a promising therapeutic target [171].

\section{Potential Strategies to Accelerate Fibrosis Reversal in Preclinical and Clinical Studies}

It is well known that liver fibrosis and even cirrhosis may reverse after removing the underlying chronic disorder. This concept is consolidated for subjects with controlled hepatitis B virus replication and for patients with chronic hepatitis C infection achiev- 
ing sustained virological response, while solid evidence for patients with alcoholic and non-alcoholic steatohepatitis is still lacking [148,172-174]. Consequently, a deeper knowledge of the mechanisms underlying fibrosis regression is needed to develop potential therapeutic approaches.

\subsection{Targeting ECM Remodeling and Sinusoidal Permeability}

Targeting ECM remodeling represents an effective strategy. Induction of macrophagemediated ECM degradation via MMPs may be helpful. Feng et al. demonstrated that in a mouse model of liver fibrosis, resolution was delayed by KC depletion and accelerated by adoptive transfer of KCs from WT animals, compared to KCs from $\mathrm{MMP9}^{-/-}$mice, suggesting that KC-derived MMP9 is essential in fibrosis reversal [135]. Selective lysyl oxidase-like 2 (LOXL2) inhibitors reduce ECM stabilization and resistance to MMP degradation by interfering with collagen and elastin cross-linking [175]. However, targeting LOXL2 in clinical trials with humanized anti-LOXL2 has shown no clinical benefit so far $[176,177]$. In order to reduce collagen 1 (Col1), Hsp47, a Col1 chaperone, was blocked in models of liver fibrosis by Hsp47 siRNA contained in vitamin A-coupled liposomes, which are predominantly taken up by HSCs, reporting anti-fibrotic actions [178]. A trial conducted with an HSP47 siRNA delivering lipid nanoparticle did not show any toxicity in healthy subjects (Soule B. et al. safety, tolerability, and pharmacokinetics of BMS-986263/ND-L02s0201, a novel targeted lipid nanoparticle delivering HSP47 siRNA, in healthy participants: a randomized, placebo-controlled, double-blind, phase 1 study-unpublished raw data). Negative modulators of LSEC dedifferentiation and activation, such as LXR $\alpha$ agonists, that also display other protective actions could be effective to revert LSEC capillarization, a prerequisite for fibrosis resolution $[169,170]$.

\subsection{Agents That Reduce the Activation of HSCs}

cAMP, a second messenger involved in several cellular responses, has been shown to promote fibrosis regression and could be a potential target to slow down fibrosis [179]. High levels of cAMP inhibit the activation of HSCs and fibroblasts, reduce their proliferation and survival, and decrease ECM synthesis [180,181]. Cilostazol is a semi-selective inhibitor of phosphodiesterase III, which increases intracellular cAMP leading to increased concentrations of the active form of protein kinase A (PKA) [182]. The use of this drug was first approved by the FDA as a treatment for intermittent claudication in 1999 [183], and it has been studied in other clinical settings displaying pleiotropic biomolecular mechanisms, including platelet inhibition, vasodilation, anti-proliferation, neuroprotection and reduction of ischemic-reperfusion injury [184-188]. This agent has also displayed antifibrotic actions in experimental nonalcoholic fatty liver disease [189] and was shown to suppress HSC activation, reducing $\mathrm{CCl}_{4}$-induced liver fibrosis [190]. Recently, cilostazol was reported to promote fibrosis regression in a TAA-induced model, through the up-regulation of hepatic cAMP and modulation of inflammation, oxidative stress, and apoptosis [191]. Amelioration of fibrosis was also observed in an alcohol-induced rat model, in which cilostazol decreased $\alpha$-SMA, collagen I and III, TGF- $\beta 1$ and connective tissue growth factor (CTGF) expression [192]. These results suggest that cilostazol could be a potential anti-fibrotic agent, although further studies are necessary to better understand its mechanisms of action. Moreover, despite its many beneficial effects, the treatment of patients with this drug must be cautious. Due to their vasodilator properties, in patients with class III to IV heart failure phosphodiesterase inhibitors have been associated with reduced survival compared with placebo. In addition, patients with history of ischemic heart disease could have a higher risk for worsening of angina pectoris or myocardial infarction [193]. Cilostazol contraindications may include tachycardia, tachyarrythmia, and/or hypotension [194]. Therefore, attention is necessary in prescribing cilostazol to patients affected by atrial or ventricular ectopy and/or by atrial fibrillation or flutter [195].

Activated HSCs increase their contractile properties in response to endothelin-1 (ET-1) via autocrine mechanisms and paracrine crosstalk with LSECs and damaged hepato- 
cytes [196]. A current clinical trial is examining the potential effect of an ET-1 receptor inhibitor in patients with cirrhosis (NCT03827200). It is well known that the renin-angiotensin system is up-regulated in cirrhotic livers [197,198]. Agents targeting this system are effective to reduce TGF- $\beta 1$ levels and the extent of fibrosis, with good safety outcomes, in fibrotic patients [199]. An undergoing clinical trial is testing the angiotensin receptor blocker, candesartan, in cirrhotic patients (NCT03770936).

Other targets include the Wnt/-catenin signaling, which plays an important role in HSC activation driving to liver fibrosis [200-202]. PRI-724, a cyclic AMP-response element binding protein (CBP)/beta-catenin inhibitor, has been observed to inhibit HSC activation and collagen production in $\mathrm{HCV}$ transgenic mice [203]. In addition, in a $\mathrm{CCl}_{4}$ murine model of liver fibrosis, PRI-724 ameliorated fibrosis owing to an increase in of $\mathrm{F} 4 / 80^{+} \mathrm{CD} 11 \mathrm{~b}^{+}$, and Ly6 $\mathrm{C}^{\text {low }} \mathrm{CD} 11 \mathrm{~b}^{+}$macrophages [124]. The CBP/beta-catenin-dependent mechanism of action of PRI-724 was well outlined in CBP KO mice [204]. A phase I clinical trial with PRI-724 conducted in HCV-associated liver cirrhosis patients showed a dose dependent histological improvement only in a few patients. NCT03620474, a phase I/II clinical trial with PRI-724 in HCV or HBV- associated liver cirrhosis patients, will be completed in 2022 and will further clarify the safety and effectiveness of PRI-724 as anti-fibrotic agent.

Farnesoid X receptor (FXR), a bile acid activated nuclear receptor mainly expressed in liver and intestine, is a key regulator of hepatic bile acid homeostasis, lipoprotein, and glucose metabolism, inflammatory responses, and liver regeneration [205-207]. FXR has been shown to exert inihibitory effects on HSCs activation [208-210]. Obeticholic acid (OCA), the first small molecule to target FXR to be approved by FDA in 2016 as a second-line treatment for primary biliary cholangitis [205], has also been used in clinical trials of patients with fibrosis. In a 2015 phase II clinical trial study (FLINT), a short-term treatment with OCA (72 weeks) improved fibrosis in NASH patients [211]. In a recent phase III clinical trial (REGENERATE) with long-term OCA treatment in NASH patients (NCT02548351) obeticholic acid $25 \mathrm{mg}$ significantly improved fibrosis and key components of NASH disease activity among patients with NASH [212].

Hepatocyte cell death triggers HSC activation [213]. The pan-caspase apoptosis inhibitor emricasan has been used in preclinical [214] and clinical studies [215,216]. While in a fibrotic rat model this agent ameliorated portal hypertension and liver fibrosis [214], the clinical trials conducted so far have not been successful $[215,216]$. Another apoptosis inhibitor tested as anti-fibrotic agent is selonsertib. This agent inhibits the activation of signal-regulating kinase 1 (ASK1), a serine/threonine signaling kinase, implicated in the activation of stress response pathways that exacerbate hepatic inflammation, apoptosis, and fibrosis (Budas $\mathrm{G}$ et al. reduction of liver steatosis and fibrosis with an ASK1 inhibitor in a murine model of NASH is accomplished by improvements in cholesterol, bile acid, and lipid metabolism -unpublished raw data). In a murine model of NASH, selonsertib significantly ameliorated not only metabolic parameters associated with NASH but also decreased hepatic steatosis, inflammation and fibrosis and in a DMN-induced fibrosis rat model it could reduce collagen deposition and the expression of $\alpha$-SMA, fibronectin, and collagen type I (Budas $\mathrm{G}$ et al. reduction of liver steatosis and fibrosis with an ASK1 inhibitor in a murine model of NASH is accomplished by improvements in cholesterol, bile acid and lipid metabolism -unpublished raw data), [217]. Based on a successful phase II clinical study enrolling NASH patients [218], two phase III clinical trials have examined the safety, and anti-fibrotic efficacy of selonsertib in NASH patients with bridging fibrosis (STELLAR-3 trial) or compensated cirrhosis (STELLAR-4 trial). While selonsertib did not show any adverse effects both trials failed to reach the primary endpoint of fibrosis improvement at week 48 [219].

\subsection{Therapeutic Targeting of Hepatic Macrophages}

There are different possible approaches for targeting hepatic macrophages for the treatment of liver diseases, including the reduction of circulating monocyte recruitment, the inhibition of KC activation and the modulation of macrophage polarization [220]. As 
previously mentioned, recruitment of proinflammatory monocytes in the injured liver is mediated by chemokines secreted by various activated liver cells that mediate a chemotactic action. Among therapeutic approaches, the modulation of chemokine signaling models using monoclonal antibodies, receptor antagonists, aptamer molecules and small molecule inhibitors has proven efficacy in various experimental models, as reported in the session of this review dedicated to CC chemokine receptor antagonists.

Another possible targeting strategy to treat liver diseases is to modulate $\mathrm{KC}$ activation, e.g., acting on surface molecules on $\mathrm{KC}$ s that have an important role in the fibrogenic process [221]. In rodent models it has been observed that galectin-3 inhibitors (GR-MD-02 and GM-CT-01) significantly decreased septal galectin-3 positive macrophages with reduction of fibrosis levels and portal pressure [222]. Galectins are carbohydrate-binding proteins in glycoproteins components of the ECM. Galectin-3 is highly expressed on KCs and plays a vital role in cell adhesion, inflammation, and fibrogenesis. GR-MD-02, a galectin-3 inhibitor, is safe and well-tolerated in subjects who had a definite histological diagnosis of NASH with advanced fibrosis, and these data provided support for a development program in advanced NASH fibrosis [223]. Recently, a phase II clinical trial of GR-MD-02 was conducted in 162 patients with NASH, cirrhosis, and portal hypertension. Although levels of fibrosis, NAFLD activity scores and liver-related outcomes did not vary significantly among groups, a subgroup analysis in patients without esophageal varices showed that GR-MD-02 therapy reduced the hepatic venous pressure gradient and development of varices. Spasmodic cough was the only adverse event related to the study drug (NCT02462967) [224]. A phase III trial has been initiated to evaluate the safety and efficacy of GR-MD-02 in patients with NASH cirrhosis without esophageal varices (NCT04365868).

Promotion of a switch from a pathogenic to a restorative phenotype is an interesting strategy to accelerate fibrosis regression and promote liver regeneration [225]. This can be achieved by using pharmacological regulators that promote macrophage polarization. Steroids (e.g., dexamethasone), IL-4, IL-10, secretory leukocyte protease inhibitor (SLPI), prostaglandin E2 (PGE2) and colony-stimulating factor 1 receptor (CSF-1R) agonists have been explored for macrophage reprogramming in liver diseases [220]. Moreover, nanoparticles [226] represent a new approach that can selectively reprogram macrophages to a restorative phenotype [220].

Different types of nano systems have been developed for the recognition and targeting of macrophages, such as liposomes, solid-lipid, polymeric or metal nanoparticles. In order to design various nanoparticle systems, it is necessary to understand their mechanism of recognition by macrophages. Another controversial issue is the possible toxicity of nondegradable nanoparticles, which in many cases accumulate in the macrophages elimination organs such as the liver, spleen, and kidneys [226].

\subsection{Exosome-Based Treatments}

Exosomes are vesicles released by cells in both physiological and pathological conditions. They can contain distinct RNAs, proteins, lipids, and metabolites depending on the cell type of origin. Following their release into the intercellular milieu, exosomes bind to recipient cells and deliver their information which is then converted into epigenetic reprogramming driving phenotypic modifications [227]. Upon liver injury, exosomes released by epithelial cells deliver information able to activate fibroblasts, resulting in increased expression of $\alpha$-SMA and type I collagen [228]. Endothelial cells release exosomes with LOXL2 located on the exterior side which increases collagen contraction [229]. Even aHSCs release exosomes containing CCN2, that contributes to the progression of fibrogenesis [230].

On the other hand, exosomes can be also involved in the regression of fibrosis [227]. Quiescent HSCs release exosomes which reduce HSC activation, while healthy hepatocytes secrete vesicles that can reduce the expression of profibrogenic genes. Alhomrani et al. identified human amnion epithelial cells secretoma as a negative modulator of liver fibrosis in CCl4 treated mice, acting on macrophage polarization, HSC activation and matrix deposition [231]. Mesenchymal stem cells (MSC)-derived exosomes are emerging as a 
potential tool to achieve liver fibrosis regression [232-234]. Exosomes released from human cord MSCs were found to ameliorate $\mathrm{CCl}_{4}$-induced hepatic fibrosis in mice, while vesicles secreted by adipose tissue-derived MSCs were able to decrease the activation and proliferation of rat HSCs $[233,234]$. Along these lines, exosomes released in the serum could be employed as antifibrotic agents, as it was recently reported that circulating exosomes from healthy mice could reduce liver fibrosis in both $\mathrm{CCl}_{4}$ - and TAA- mouse models [234]. In conclusion, "healthy exosomes", containing "therapeutic factors", emerge as a potential and powerful instrument for fibrotic liver treatment [234].

\subsection{Mesenchymal Stem Cell Transplantation}

Transplantation of stem cells, including MSCs, endothelial progenitors and haemopoietic stem cells, has proven to be effective in repairing fibrotic livers in experimental models, stimulating hepatocyte proliferation, inhibiting aHSCs, increasing MMP activity and inducing neovascularization [235]. MSCs have high proliferative capacity and multilineage potential and, when transplanted, migrate to fibrotic areas, and differentiate into hepatocyte-like cells or fuse with hepatocytes to restore liver function [235]. Human palatine tonsil-derived MSCs were shown to migrate to damaged livers but not to healthy livers. These cells, differentiating into hepatocyte-like cells, stimulated autophagy and decreased TGF- $\beta$ signaling pathways, hampering liver fibrosis [236]. MSC transplantation was shown to improve hepatobiliary fibrosis, by inhibiting activation of HSCs, reducing collagen deposition, and increasing ECM degradation through an increase in MMP13 and a decrease of TIMP-1 [237,238].

Clinical trials have been conducted to test the efficacy of MSC transplantation, with controversial results. In cirrhotic patients MSCs were found to exert protective effects by increasing the amount of Treg cells and decreasing Th17 cells, leading to diminished serum levels of TGF- $\beta$, IL-17, TNF- $\alpha$, and IL-6 [239]. In HBV-induced cirrhosis, MSC transfusion demonstrated to be clinically safe and to decrease ascites [240]. In other studies, MSC transplantation had no beneficial effects [241,242]. These discrepant results are probably due to the restricted number of patients enrolled and the short-term of follow up. Further investigation is warranted to elucidate the efficacy and the safety of this therapy for the treatment of fibrotic and cirrhotic patients. The main therapeutic approaches aimed to achieve the regression of fibrosis are summarized in Table 2.

Table 2. Major therapeutic approaches aimed to promote fibrosis regression.

\begin{tabular}{|c|c|c|c|c|}
\hline THERAPY & TARGET(S) & $\begin{array}{l}\text { MECHANISM(S) OF } \\
\text { ACTION }\end{array}$ & $\begin{array}{l}\text { PRE-CLINICAL OR } \\
\text { CLINICAL STUDIES }\end{array}$ & STUDIES \\
\hline LOXL2 inhibitors & $\begin{array}{l}\text { Collagen and elastin } \\
\text { cross-linking }\end{array}$ & $\begin{array}{c}\text { Reduction of ECM } \\
\text { stabilization and resistance } \\
\text { to MMP degradation }\end{array}$ & $\begin{array}{l}\text { Pre-clinical and clinical } \\
\text { studies }\end{array}$ & [175-177] \\
\hline Cilostazol & Phosphodiesterase III & $\begin{array}{l}\text { Increase in intracellular } \\
\text { cAMP with consequent } \\
\text { inhibition of HSC and } \\
\text { fibroblast activation }\end{array}$ & Pre-clinical studies & [189-192] \\
\hline ET-1 receptor inhibitor & Endothelin-1 (ET-1) & $\begin{array}{l}\text { Decrease in the contractile } \\
\text { capacity of aHSCs mediated } \\
\text { by interaction with LSEC } \\
\text { and damaged hepatocytes }\end{array}$ & $\begin{array}{l}\text { Pre-clinical and clinical } \\
\text { studies }\end{array}$ & $\begin{array}{c}{[196]} \\
(\mathrm{NCT03827200)}\end{array}$ \\
\hline $\begin{array}{l}\text { RAS inhibitor therapy } \\
\text { (Candesartan) }\end{array}$ & TGF $\beta 1$ & Reduction of liver fibrosis & $\begin{array}{l}\text { Pre-clinical and clinical } \\
\text { studies }\end{array}$ & $\begin{array}{c}{[199]} \\
(\mathrm{NCT03770936)}\end{array}$ \\
\hline Exosome-based treatments & $\begin{array}{l}\text { Profibrogenic factors } \\
(\alpha-S M A, T G F \beta 1)\end{array}$ & $\begin{array}{l}\text { Modulation of macrophage } \\
\text { polarization, suppression of } \\
\text { HSC activation and matrix } \\
\text { deposition }\end{array}$ & Pre-clinical studies & {$[227,231-234]$} \\
\hline $\begin{array}{l}\text { Mesenchymal stem cell } \\
\text { transplantation }\end{array}$ & $\begin{array}{l}\text { Promote MSC migration } \\
\text { into the fibrotic areas and } \\
\text { their differentiation into } \\
\text { hepatocyte-like cells to } \\
\text { restore liver function }\end{array}$ & $\begin{array}{l}\text { Stimulation of hepatocyte } \\
\text { proliferation, reduction of } \\
\text { HSC activation, increase in } \\
\text { MMP activity and } \\
\text { promotion of } \\
\text { neovascularization }\end{array}$ & $\begin{array}{l}\text { Pre-clinical and clinical } \\
\text { studies }\end{array}$ & {$[232,235-242]$} \\
\hline
\end{tabular}




\subsection{Chemokine Receptor Antagonists}

Chemokines coordinate inflammatory responses within different organs and induce the migration of fibrogenic cells to the sites of injury, thereby boosting fibrogenesis [110]. It has been observed that CCL5/RANTES, a ligand of chemokine receptor CCR5 induced by $\mathrm{NF} K \mathrm{~B}$ signaling, increased HSC migration and proliferation [243]. In experimental models of liver fibrosis (CCl4 and bile duct ligation), CCR1- and CCR5-knockout mice showed decreased hepatic fibrosis and macrophage infiltration [244]. An oral dual CCR2/CCR5 inhibitor, Cenicriviroc (CVC), showed anti-fibrotic effects in a thioacetamide-induced rodent model [245]. A phase II study using CVC, was conducted in NASH patients with liver fibrosis showing a beneficial effect of this agent even if not accompanied by antiinflammatory action. Of note, treatment benefits were mostly shown in patients who showed higher fibrosis stage at baseline [246]. A phase III study (AURORA) in NASH patients with more advanced fibrosis was concluded early due to lack of efficacy of CVC based on the results of part I of the trial.

\section{Conclusions}

As well as fibrosis development, fibrosis regression is a complex and tightly regulated process that involves various cell types and several molecules, differently acting according to the changes in the ECM/inflammatory-driven microenvironment. Although reversal of fibrosis appears an encouraging approach to the treatment of chronic liver diseases, further studies are necessary to better understand the mechanisms underlying this process and to identify novel therapies for chronic liver disease. This could imply a decreased risk of developing hepatocellular carcinoma in patients affected by chronic liver disorders. In addition, while current therapies aimed to promote regression of fibrosis mainly focus on the removal of the noxious agents, there is need to deeper investigate on anti-fibrotic treatments able to positively modulate the mechanisms favoring fibrosis regression to confirm the long-term impact and strength of these findings. Indeed, even if some therapies or agents could represent promising tools to resolve hepatic fibrosis, none of the ones already used in human studies have been approved for clinical treatment.

Funding: This work has been supported by the European Commission (Projects EpoS and LITMUS) and by the University of Florence.

Conflicts of Interest: The authors declare no conflict of interest.

$\begin{array}{ll}\text { Abbreviations } \\ \text { HSCs } & \text { hepatic stellate cells } \\ \mathrm{ECM} & \text { extracellular matrix } \\ \mathrm{NK} & \text { natural killer } \\ \mathrm{CCl}_{4} & \text { carbon tetrachloride } \\ \mathrm{TAA} & \text { thioacetamide } \\ \mathrm{BDL} & \text { bile duct ligation } \\ \mathrm{EMT} & \text { epithelial-mesenchymal transition } \\ \mathrm{MMPs} & \text { matrix metalloproteases } \\ \text { KCs } & \text { Kupffer cells } \\ \text { TIMPs } & \text { tissue inhibitors of metalloproteases } \\ \text { LSECs } & \text { liver sinusoidal endothelial cells } \\ \text { LOXL2 } & \text { lysyl oxidase-like } 2 \\ \text { RAS } & \text { renin-angiotensin system } \\ \text { MSCs } & \text { mesenchymal stem cells }\end{array}$




\begin{tabular}{|c|c|}
\hline cAMP & cyclic adenosine monophosphate \\
\hline PKA & protein kinase A \\
\hline CTGF & connective tissue growth factor \\
\hline OCA & obeticholic acid \\
\hline$\alpha$-SMA & $\alpha$-smooth muscle actin \\
\hline SLPI & secretory leukocyte protease inhibitor \\
\hline PGE2 & prostaglandin E2 \\
\hline CSF-1R & colony-stimulating factor 1 receptor \\
\hline TG & triacylglycerol \\
\hline DAAs & direct-acting antivirals \\
\hline $\mathrm{Hh}$ & Hedgehog \\
\hline HIF & hypoxia-inducible factor \\
\hline IL & interleukin \\
\hline $\mathrm{HCC}$ & hepatocellular carcinoma \\
\hline VEGF & vascular endothelial growth factor \\
\hline
\end{tabular}

\section{References}

1. Pinzani, M.; Rombouts, K.; Colagrande, S. Fibrosis in chronic liver diseases: Diagnosis and management. J. Hepatol. 2005, 42 (Suppl. 1), S22-S36. [CrossRef] [PubMed]

2. Khurana, A.; Sayed, N.; Allawadhi, P.; Weiskirchen, R. It's all about the spaces between cells: Role of extracellular matrix in liver fibrosis. Ann. Transl. Med. 2021, 9, 728. [CrossRef] [PubMed]

3. Zoubek, M.E.; Trautwein, C.; Strnad, P. Reversal of liver fibrosis: From fiction to reality. Best Pract. Res. Clin. Gastroenterol. 2017, 31, 129-141. [CrossRef] [PubMed]

4. Tacke, F.; Trautwein, C. Mechanisms of liver fibrosis resolution. J. Hepatol. 2015, 63, 1038-1039. [CrossRef]

5. Weiskirchen, R.; Weiskirchen, S.; Tacke, F. Organ and tissue fibrosis: Molecular signals, cellular mechanisms and translational implications. Mol. Asp. Med. 2019, 65, 2-15. [CrossRef]

6. Cordero-Espinoza, L.; Huch, M. The balancing act of the liver: Tissue regeneration versus fibrosis. J. Clin. Investig. 2018, 128, 85-96. [CrossRef]

7. Jun, J.I.; Lau, L.F. Resolution of organ fibrosis. J. Clin. Investig. 2018, 128, 97-107. [CrossRef]

8. Krenkel, O.; Puengel, T.; Govaere, O.; Abdallah, A.T.; Mossanen, J.C.; Kohlhepp, M.; Liepelt, A.; Lefebvre, E.; Luedde, T.; Hellerbrand, C.; et al. Therapeutic inhibition of inflammatory monocyte recruitment reduces steatohepatitis and liver fibrosis. Hepatology 2018, 67, 1270-1283. [CrossRef]

9. Gieseck, R.L.; Wilson, M.S.; Wynn, T.A. Type 2 immunity in tissue repair and fibrosis. Nat. Rev. Immunol. 2018, 18, 62-76. [CrossRef]

10. Karsdal, M.A.; Nielsen, S.H.; Leeming, D.J.; Langholm, L.L.; Nielsen, M.J.; Manon-Jensen, T.; Siebuhr, A.; Gudmann, N.S.; Rønnow, S.; Sand, J.M.; et al. The good and the bad collagens of fibrosis-Their role in signaling and organ function. Adv. Drug Deliv. Rev. 2017, 121, 43-56. [CrossRef]

11. Marcellin, P.; Gane, E.; Buti, M.; Afdhal, N.; Sievert, W.; Jacobson, I.M.; Washington, M.K.; Germanidis, G.; Flaherty, J.F.; Aguilar Schall, R.; et al. Regression of cirrhosis during treatment with tenofovir disoproxil fumarate for chronic hepatitis B: A 5-year open-label follow-up study. Lancet 2013, 381, 468-475. [CrossRef]

12. D'Ambrosio, R.; Aghemo, A.; Rumi, M.G.; Ronchi, G.; Donato, M.F.; Paradis, V.; Colombo, M.; Bedossa, P. A morphometric and immunohistochemical study to assess the benefit of a sustained virological response in hepatitis $C$ virus patients with cirrhosis. Hepatology 2012, 56, 532-543. [CrossRef]

13. Schuppan, D.; Surabattula, R.; Wang, X.Y. Determinants of fibrosis progression and regression in NASH. J. Hepatol. 2018, 68, 238-250. [CrossRef]

14. Kisseleva, T.; Cong, M.; Paik, Y.; Scholten, D.; Jiang, C.; Benner, C.; Iwaisako, K.; Moore-Morris, T.; Scott, B.; Tsukamoto, H.; et al. Myofibroblasts revert to an inactive phenotype during regression of liver fibrosis. Proc. Natl. Acad. Sci. USA 2012, 109, 9448-9453. [CrossRef]

15. Troeger, J.S.; Mederacke, I.; Gwak, G.Y.; Dapito, D.H.; Mu, X.; Hsu, C.C.; Pradere, J.P.; Friedman, R.A.; Schwabe, R.F. Deactivation of hepatic stellate cells during liver fibrosis resolution in mice. Gastroenterology 2012, 143, 1073-1083. [CrossRef]

16. Scorza, M.; Elce, A.; Zarrilli, F.; Liguori, R.; Amato, F.; Castaldo, G. Genetic diseases that predispose to early liver cirrhosis. Int. J. Hepatol. 2014, 2014, 713754. [CrossRef]

17. Acharya, P.; Chouhan, K.; Weiskirchen, S.; Weiskirchen, R. Cellular mechanisms of liver fibrosis. Front. Pharmacol. 2021, 12, 671640. [CrossRef]

18. Pinto, R.B.; Schneider, A.C.; Da Silveira, T.R. Cirrhosis in children and adolescents: An overview. World J. Hepatol. 2015, 7, $392-405$. [CrossRef] 
19. Anstee, Q.M.; Darlay, R.; Cockell, S.; Meroni, M.; Govaere, O.; Tiniakos, D.; Burt, A.D.; Bedossa, P.; Palmer, J.; Liu, Y.L.; et al. Genome-wide association study of non-alcoholic fatty liver and steatohepatitis in a histologically characterised cohort. J. Hepatol. 2020, 73, 505-515. [CrossRef]

20. Dong, X.C. PNPLA3-A potential therapeutic target for personalized treatment of chronic liver disease. Front. Med. 2019, 6, 304. [CrossRef]

21. Huang, Y.; Cohen, J.C.; Hobbs, H.H. Expression and characterization of a PNPLA3 protein isoform (I148M) associated with nonalcoholic fatty liver disease. J. Biol. Chem. 2011, 286, 37085-37093. [CrossRef]

22. Caligiuri, A.; Gentilini, A.; Marra, F. Molecular pathogenesis of NASH. Int. J. Mol. Sci. 2016, 17, 1575. [CrossRef]

23. Gentilini, A.; Caligiuri, A.; Provenzano, A.; Marra, F. Novel aspects in the pathogenesis of nonalcoholic steatohepatitis. Curr. Mol. Med. 2016, 16, 710-720. [CrossRef]

24. Chen, W.; Chang, B.; Li, L.; Chan, L. Patatin-like phospholipase domain-containing 3/adiponutrin deficiency in mice is not associated with fatty liver disease. Hepatology 2010, 52, 1134-1142. [CrossRef] [PubMed]

25. He, S.; McPhaul, C.; Li, J.Z.; Garuti, R.; Kinch, L.; Grishin, N.V.; Cohen, J.C.; Hobbs, H.H. A sequence variation (I148M) in PNPLA3 associated with nonalcoholic fatty liver disease disrupts triglyceride hydrolysis. J. Biol. Chem. 2010, 285, 6706-6715. [CrossRef] [PubMed]

26. Wang, Y.; Kory, N.; BasuRay, S.; Cohen, J.C.; Hobbs, H.H. PNPLA3, CGI-58, and inhibition of hepatic triglyceride hydrolysis in mice. Hepatology 2019, 69, 2427-2441. [CrossRef] [PubMed]

27. Murugesan, S.; Goldberg, E.B.; Dou, E.; Brown, W.J. Identification of diverse lipid droplet targeting motifs in the PNPLA family of triglyceride lipases. PLoS ONE 2013, 8, e64950. [CrossRef] [PubMed]

28. Chamoun, Z.; Vacca, F.; Parton, R.G.; Gruenberg, J. PNPLA3/adiponutrin functions in lipid droplet formation. Biol. Cell 2013, 105, 219-233. [CrossRef]

29. BasuRay, S.; Smagris, E.; Cohen, J.C.; Hobbs, H.H. The PNPLA3 variant associated with fatty liver disease (I148M) accumulates on lipid droplets by evading ubiquitylation. Hepatology 2017, 66, 1111-1124. [CrossRef]

30. BasuRay, S.; Wang, Y.; Smagris, E.; Cohen, J.C.; Hobbs, H.H. Accumulation of PNPLA3 on lipid droplets is the basis of associated hepatic steatosis. Proc. Natl. Acad. Sci. USA 2019, 116, 9521-9526. [CrossRef]

31. Negoita, F.; Blomdahl, J.; Wasserstrom, S.; Winberg, M.E.; Osmark, P.; Larsson, S.; Stenkula, K.G.; Ekstedt, M.; Kechagias, S.; Holm, C.; et al. PNPLA3 variant M148 causes resistance to starvation-mediated lipid droplet autophagy in human hepatocytes. J. Cell. Biochem. 2019, 120, 343-356. [CrossRef]

32. Hellemans, K.; Grinko, I.; Rombouts, K.; Schuppan, D.; Geerts, A. All-trans and 9-cis retinoic acid alter rat hepatic stellate cell phenotype differentially. Gut 1999, 45, 134-142. [CrossRef]

33. Wang, L.; Tankersley, L.R.; Tang, M.; Potter, J.J.; Mezey, E. Regulation of the murine alpha(2)(I) collagen promoter by retinoic acid and retinoid X receptors. Arch. Biochem. Biophys. 2002, 401, 262-270. [CrossRef]

34. Bruschi, F.V.; Claudel, T.; Tardelli, M.; Caligiuri, A.; Stulnig, T.M.; Marra, F.; Trauner, M. The PNPLA3 I148M variant modulates the fibrogenic phenotype of human hepatic stellate cells. Hepatology 2017, 65, 1875-1890. [CrossRef]

35. Götze, S.; Schumacher, E.C.; Kordes, C.; Häussinger, D. Epigenetic changes during hepatic stellate cell activation. PLoS ONE 2015, 10, e0128745. [CrossRef]

36. Jiang, F.; Parsons, C.J.; Stefanovic, B. Gene expression profile of quiescent and activated rat hepatic stellate cells implicates Wnt signaling pathway in activation. J. Hepatol. 2006, 45, 401-409. [CrossRef]

37. Bian, E.B.; Huang, C.; Ma, T.T.; Tao, H.; Zhang, H.; Cheng, C.; Lv, X.W.; Li, J. DNMT1-mediated PTEN hypermethylation confers hepatic stellate cell activation and liver fibrogenesis in rats. Toxicol. Appl. Pharmacol. 2012, 264, 13-22. [CrossRef]

38. El Taghdouini, A.; Sørensen, A.L.; Reiner, A.H.; Coll, M.; Verhulst, S.; Mannaerts, I.; Øie, C.I.; Smedsrød, B.; Najimi, M.; Sokal, E.; et al. Genome-wide analysis of DNA methylation and gene expression patterns in purified, uncultured human liver cells and activated hepatic stellate cells. Oncotarget 2015, 6, 26729-26745. [CrossRef]

39. Page, A.; Paoli, P.; Moran Salvador, E.; White, S.; French, J.; Mann, J. Hepatic stellate cell transdifferentiation involves genome-wide remodeling of the DNA methylation landscape. J. Hepatol. 2016, 64, 661-673. [CrossRef]

40. Zeybel, M.; Hardy, T.; Wong, Y.K.; Mathers, J.C.; Fox, C.R.; Gackowska, A.; Oakley, F.; Burt, A.D.; Wilson, C.L.; Anstee, Q.M.; et al. Multigenerational epigenetic adaptation of the hepatic wound-healing response. Nat. Med. 2012, 18, 1369-1377. [CrossRef]

41. Liu, Y.; Wang, Z.; Wang, J.; Lam, W.; Kwong, S.; Li, F.; Friedman, S.L.; Zhou, S.; Ren, Q.; Xu, Z.; et al. A histone deacetylase inhibitor, largazole, decreases liver fibrosis and angiogenesis by inhibiting transforming growth factor- $\beta$ and vascular endothelial growth factor signalling. Liver Int. 2013, 33, 504-515. [CrossRef]

42. Park, K.C.; Park, J.H.; Jeon, J.Y.; Kim, S.Y.; Kim, J.M.; Lim, C.Y.; Lee, T.H.; Kim, H.K.; Lee, H.G.; Kim, S.M.; et al. A new histone deacetylase inhibitor improves liver fibrosis in BDL rats through suppression of hepatic stellate cells. Br. J. Pharmacol. 2014, 171, 4820-4830. [CrossRef]

43. Shaker, M.E.; Ghani, A.; Shiha, G.E.; Ibrahim, T.M.; Mehal, W.Z. Nilotinib induces apoptosis and autophagic cell death of activated hepatic stellate cells via inhibition of histone deacetylases. Biochim. Biophys. Acta 2013, 1833, 1992-2003. [CrossRef]

44. Pang, M.; Kothapally, J.; Mao, H.; Tolbert, E.; Ponnusamy, M.; Chin, Y.E.; Zhuang, S. Inhibition of histone deacetylase activity attenuates renal fibroblast activation and interstitial fibrosis in obstructive nephropathy. Am. J. Physiol. Physiol. 2009, 297, F996-F1005. [CrossRef] 
45. Davies, E.R.; Haitchi, H.M.; Thatcher, T.H.; Sime, P.J.; Kottmann, R.M.; Ganesan, A.; Packham, G.; O’Reilly, K.M.; Davies, D.E. Spiruchostatin A inhibits proliferation and differentiation of fibroblasts from patients with pulmonary fibrosis. Am. J. Respir. Cell Mol. Biol. 2012, 46, 687-694. [CrossRef]

46. Kirpich, I.; Zhang, J.; Gobejishvili, L.; Kharebava, G.; Barker, D.; Ghare, S.; Joshi-Barve, S.; McClain, C.J.; Barve, S. Binge ethanol-induced HDAC3 down-regulates Cpt1 $\alpha$ expression leading to hepatic steatosis and injury. Alcohol. Clin. Exp. Res. 2013, 37, 1920-1929. [CrossRef]

47. Watanabe, T.; Tajima, H.; Hironori, H.; Nakagawara, H.; Ohnishi, I.; Takamura, H.; Ninomiya, I.; Kitagawa, H.; Fushida, S.; Tani, T.; et al. Sodium valproate blocks the transforming growth factor (TGF)- $\beta 1$ autocrine loop and attenuates the TGF- $\beta 1$-induced collagen synthesis in a human hepatic stellate cell line. Int. J. Mol. Med. 2011, 28, 919-925. [CrossRef]

48. Ding, D.; Chen, L.L.; Zhai, Y.Z.; Hou, C.J.; Tao, L.L.; Lu, S.H.; Wu, J.; Liu, X.P. Trichostatin A inhibits the activation of Hepatic stellate cells by Increasing C/EBP- $\alpha$ Acetylation in vivo and in vitro. Sci. Rep. 2018, 8, 4395. [CrossRef]

49. Iwaisako, K.; Brenner, D.A.; Kisseleva, T. What's new in liver fibrosis? The origin of myofibroblasts in liver fibrosis. J. Gastroenterol. Hepatol. 2012, 27 (Suppl. 2), 65-68. [CrossRef]

50. Iwaisako, K.; Jiang, C.; Zhang, M.; Cong, M.; Moore-Morris, T.J.; Park, T.J.; Liu, X.; Xu, J.; Wang, P.; Paik, Y.H.; et al. Origin of myofibroblasts in the fibrotic liver in mice. Proc. Natl. Acad. Sci. USA 2014, 111, E3297-E3305. [CrossRef]

51. Puche, J.E.; Lee, Y.A.; Jiao, J.; Aloman, C.; Fiel, M.I.; Muñoz, U.; Kraus, T.; Lee, T.; Yee, H.F.; Friedman, S.L. A novel murine model to deplete hepatic stellate cells uncovers their role in amplifying liver damage in mice. Hepatology 2013, 57, 339-350. [CrossRef] [PubMed]

52. Krizhanovsky, V.; Yon, M.; Dickins, R.A.; Hearn, S.; Simon, J.; Miething, C.; Yee, H.; Zender, L.; Lowe, S.W. Senescence of activated stellate cells limits liver fibrosis. Cell 2008, 134, 657-667. [CrossRef]

53. Iredale, J.P.; Benyon, R.C.; Pickering, J.; McCullen, M.; Northrop, M.; Pawley, S.; Hovell, C.; Arthur, M.J. Mechanisms of spontaneous resolution of rat liver fibrosis. Hepatic stellate cell apoptosis and reduced hepatic expression of metalloproteinase inhibitors. J. Clin. Investig. 1998, 102, 538-549. [CrossRef] [PubMed]

54. Kong, D.; Zhang, F.; Zhang, Z.; Lu, Y.; Zheng, S. Clearance of activated stellate cells for hepatic fibrosis regression: Molecular basis and translational potential. Biomed. Pharmacother. 2013, 67, 246-250. [CrossRef] [PubMed]

55. Huang, Y.; Deng, X.; Liang, J. Modulation of hepatic stellate cells and reversibility of hepatic fibrosis. Exp. Cell Res. 2017, 352, 420-426. [CrossRef]

56. Mallat, A.; Lotersztajn, S. The liver X receptor in hepatic stellate cells: A novel antifibrogenic target? J. Hepatol. 2011, 55, 1452-1454. [CrossRef]

57. Ban, D.; Hua, S.; Zhang, W.; Shen, C.; Miao, X.; Liu, W. Costunolide reduces glycolysis-associated activation of hepatic stellate cells via inhibition of hexokinase-2. Cell. Mol. Biol. Lett. 2019, 24, 52. [CrossRef]

58. Claeyssen, E.; Rivoal, J. Isozymes of plant hexokinase: Occurrence, properties and functions. Phytochemistry 2007, 68, 709-731. [CrossRef]

59. Hou, W.; Syn, W.K. Role of metabolism in hepatic stellate cell activation and fibrogenesis. Front. Cell Dev. Biol. 2018, 6, 150. [CrossRef]

60. Li, J.; Ghazwani, M.; Liu, K.; Huang, Y.; Chang, N.; Fan, J.; He, F.; Li, L.; Bu, S.; Xie, W.; et al. Regulation of hepatic stellate cell proliferation and activation by glutamine metabolism. PLoS ONE 2017, 12, e0182679. [CrossRef]

61. Du, K.; Hyun, J.; Premont, R.T.; Choi, S.S.; Michelotti, G.A.; Swiderska-Syn, M.; Dalton, G.D.; Thelen, E.; Rizi, B.S.; Jung, Y.; et al. Hedgehog-YAP signaling pathway regulates glutaminolysis to control activation of hepatic stellate cells. Gastroenterology 2018, 154, 1465-1479. [CrossRef]

62. Bataller, R.; Brenner, D.A. Liver fibrosis. J. Clin. Investig. 2005, 115, 209-218. [CrossRef]

63. Dhar, D.; Baglieri, J.; Kisseleva, T.; Brenner, D.A. Mechanisms of liver fibrosis and its role in liver cancer. Exp. Biol. Med. 2020, 245, 96-108. [CrossRef]

64. Issa, R.; Williams, E.; Trim, N.; Kendall, T.; Arthur, M.J.; Reichen, J.; Benyon, R.C.; Iredale, J.P. Apoptosis of hepatic stellate cells: Involvement in resolution of biliary fibrosis and regulation by soluble growth factors. Gut 2001, 48, 548-557. [CrossRef]

65. Oh, Y.; Park, O.; Swierczewska, M.; Hamilton, J.P.; Park, J.S.; Kim, T.H.; Lim, S.M.; Eom, H.; Jo, D.G.; Lee, C.E.; et al. Systemic PEGylated TRAIL treatment ameliorates liver cirrhosis in rats by eliminating activated hepatic stellate cells. Hepatology 2016, 64, 209-223. [CrossRef]

66. Park, S.J.; Sohn, H.Y.; Yoon, J.; Park, S.I. Down-regulation of FoxO-dependent c-FLIP expression mediates TRAIL-induced apoptosis in activated hepatic stellate cells. Cell. Signal. 2009, 21, 1495-1503. [CrossRef]

67. Yang, J.; Liu, Q.; Cao, S.; Xu, T.; Li, X.; Zhou, D.; Pan, L.; Li, C.; Huang, C.; Meng, X.; et al. MicroRNA-145 increases the apoptosis of activated hepatic stellate cells induced by TRAIL through NF-kB signaling pathway. Front. Pharmacol. 2017, 8, 980. [CrossRef]

68. Siegmund, S.V.; Wojtalla, A.; Schlosser, M.; Schildberg, F.A.; Knolle, P.A.; Nüsing, R.M.; Zimmer, A.; Strassburg, C.P.; Singer, M.V. Cyclooxygenase-2 contributes to the selective induction of cell death by the endocannabinoid 2-arachidonoyl glycerol in hepatic stellate cells. Biochem. Biophys. Res. Commun. 2016, 470, 678-684. [CrossRef]

69. Ding, Q.; Xie, X.L.; Wang, M.M.; Yin, J.; Tian, J.M.; Jiang, X.Y.; Zhang, D.; Han, J.; Bai, Y.; Cui, Z.J.; et al. The role of the apoptosis-related protein BCL-B in the regulation of mitophagy in hepatic stellate cells during the regression of liver fibrosis. Exp. Mol. Med. 2019, 51, 1-13. [CrossRef] 
70. Panebianco, C.; Oben, J.A.; Vinciguerra, M.; Pazienza, V. Senescence in hepatic stellate cells as a mechanism of liver fibrosis reversal: A putative synergy between retinoic acid and PPAR-gamma signalings. Clin. Exp. Med. 2017, 17, 269-280. [CrossRef]

71. Campisi, J.; Di Fagagna, F.D.A. Cellular senescence: When bad things happen to good cells. Nat. Rev. Mol. Cell. Biol. 2007, 8, 729-740. [CrossRef] [PubMed]

72. Kuilman, T.; Michaloglou, C.; Mooi, W.J.; Peeper, D.S. The essence of senescence. Genes Dev. 2010, 24, 2463-2479. [CrossRef] [PubMed]

73. Rodier, F.; Campisi, J. Four faces of cellular senescence. J. Cell Biol. 2011, 192, 547-556. [CrossRef] [PubMed]

74. Kim, K.H.; Chen, C.C.; Monzon, R.I.; Lau, L.F. Matricellular protein CCN1 promotes regression of liver fibrosis through induction of cellular senescence in hepatic myofibroblasts. Mol. Cell. Biol. 2013, 33, 2078-2090. [CrossRef]

75. Huang, Y.H.; Chen, M.H.; Guo, Q.L.; Chen, Y.X.; Zhang, L.J.; Chen, Z.X.; Wang, X.Z. Interleukin-10 promotes primary rat hepatic stellate cell senescence by upregulating the expression levels of p53 and p21. Mol. Med. Rep. 2018, 17, 5700-5707. [CrossRef]

76. Chen, E.; Cen, Y.; Lu, D.; Luo, W.; Jiang, H. IL-22 inactivates hepatic stellate cells via downregulation of the TGF- $\beta 1 /$ Notch signaling pathway. Mol. Med. Rep. 2018, 17, 5449-5453. [CrossRef]

77. Zhang, J.; Wang, M.; Zhang, Z.; Luo, Z.; Liu, F.; Liu, J. Celecoxib derivative OSU-03012 inhibits the proliferation and activation of hepatic stellate cells by inducing cell senescence. Mol. Med. Rep. 2014, 11, 3021-3026. [CrossRef]

78. Zhai, X.; Qiao, H.; Guan, W.; Li, Z.; Cheng, Y.; Jia, X.; Zhou, Y. Curcumin regulates peroxisome proliferator-activated receptor- $\gamma$ coactivator-1 $\alpha$ expression by AMPK pathway in hepatic stellate cells in vitro. Eur. J. Pharmacol. 2015, 746, 56-62. [CrossRef]

79. Duffield, J.S.; Forbes, S.J.; Constandinou, C.M.; Clay, S.; Partolina, M.; Vuthoori, S.; Wu, S.; Lang, R.; Iredale, J.P. Selective depletion of macrophages reveals distinct, opposing roles during liver injury and repair. J. Clin. Investig. 2005, 115, 56-65. [CrossRef]

80. Kisseleva, T.; Brenner, D.A. Hepatic stellate cells and the reversal of fibrosis. J. Gastroenterol. Hepatol. 2006, 21 (Suppl. 3), S84-S87. [CrossRef]

81. Gao, B.; Radaeva, S.; Park, O. Liver natural killer and natural killer T cells: Immunobiology and emerging roles in liver diseases. J. Leukoc. Biol. 2009, 86, 513-528. [CrossRef]

82. Kisseleva, T.; Brenner, D.A. Mechanisms of fibrogenesis. Exp. Biol. Med. 2008, 233, 109-122. [CrossRef]

83. Mitra, A.; Satelli, A.; Yan, J.; Xueqing, X.; Gagea, M.; Hunter, C.A.; Mishra, L.; Li, S. IL-30 (IL27p28) attenuates liver fibrosis through inducing NKG2D-rae1 interaction between NKT and activated hepatic stellate cells in mice. Hepatology 2014, 60, 2027-2039. [CrossRef]

84. Radaeva, S.; Sun, R.; Jaruga, B.; Nguyen, V.T.; Tian, Z.; Gao, B. Natural killer cells ameliorate liver fibrosis by killing activated stellate cells in NKG2D-dependent and tumor necrosis factor-related apoptosis-inducing ligand-dependent manners. Gastroenterology 2006, 130, 435-452. [CrossRef]

85. Li, T.; Yang, Y.; Song, H.; Li, H.; Cui, A.; Liu, Y.; Su, L.; Crispe, I.N.; Tu, Z. Activated NK cells kill hepatic stellate cells via p38/PI3K signaling in a TRAIL-involved degranulation manner. J. Leukoc. Biol. 2019, 105, 695-704. [CrossRef]

86. Glässner, A.; Eisenhardt, M.; Krämer, B.; Körner, C.; Coenen, M.; Sauerbruch, T.; Spengler, U.; Nattermann, J. NK cells from HCV-infected patients effectively induce apoptosis of activated primary human hepatic stellate cells in a TRAIL-, FasL- and NKG2D-dependent manner. Lab. Investig. 2012, 92, 967-977. [CrossRef]

87. Gao, B.; Radaeva, S. Natural killer and natural killer T cells in liver fibrosis. Biochim. Biophys. Acta 2013, 1832, 1061-1069. [CrossRef]

88. Jeong, W.I.; Park, O.; Suh, Y.G.; Byun, J.S.; Park, S.Y.; Choi, E.; Kim, J.K.; Ko, H.; Wang, H.; Miller, A.M.; et al. Suppression of innate immunity (natural killer cell/interferon- $\gamma$ ) in the advanced stages of liver fibrosis in mice. Hepatology 2011, 53, 1342-1351. [CrossRef]

89. Wynn, T.A.; Ramalingam, T.R. Mechanisms of fibrosis: Therapeutic translation for fibrotic disease. Nat. Med. 2012, 18, 1028-1040. [CrossRef]

90. Kong, X.; Feng, D.; Wang, H.; Hong, F.; Bertola, A.; Wang, F.S.; Gao, B. Interleukin-22 induces hepatic stellate cell senescence and restricts liver fibrosis in mice. Hepatology 2012, 56, 1150-1159. [CrossRef]

91. Liu, M.; Hu, Y.; Yuan, Y.; Tian, Z.; Zhang, C. $\gamma \delta$ T Cells suppress liver fibrosis via strong cytolysis and enhanced NK cell-mediated cytotoxicity against hepatic stellate cells. Front. Immunol. 2019, 10, 477. [CrossRef] [PubMed]

92. Faggioli, F.; Palagano, E.; Di Tommaso, L.; Donadon, M.; Marrella, V.; Recordati, C.; Mantero, S.; Villa, A.; Vezzoni, P.; Cassani, B. B lymphocytes limit senescence-driven fibrosis resolution and favor hepatocarcinogenesis in mouse liver injury. Hepatology 2018, 67, 1970-1985. [CrossRef] [PubMed]

93. Song, G.; Pacher, M.; Balakrishnan, A.; Yuan, Q.; Tsay, H.C.; Yang, D.; Reetz, J.; Brandes, S.; Dai, Z.; Pützer, B.M.; et al. Direct reprogramming of hepatic myofibroblasts into hepatocytes in vivo attenuates liver fibrosis. Cell Stem Cell 2016, 18, 797-808. [CrossRef] [PubMed]

94. Nakano, Y.; Kamiya, A.; Sumiyoshi, H.; Tsuruya, K.; Kagawa, T.; Inagaki, Y. A deactivation factor of fibrogenic hepatic stellate cells induces regression of liver fibrosis in mice. Hepatology 2020, 71, 1437-1452. [CrossRef]

95. She, H.; Xiong, S.; Hazra, S.; Tsukamoto, H. Adipogenic transcriptional regulation of hepatic stellate cells. J. Biol. Chem. 2005, 280, 4959-4967. [CrossRef]

96. El Taghdouini, A.; Najimi, M.; Sancho-Bru, P.; Sokal, E.; Van Grunsven, L.A. In vitro reversion of activated primary human hepatic stellate cells. Fibrogenesis Tissue Repair 2015, 8, 14. [CrossRef] 
97. Caliari, S.R.; Perepelyuk, M.; Soulas, E.M.; Lee, G.Y.; Wells, R.G.; Burdick, J.A. Gradually softening hydrogels for modeling hepatic stellate cell behavior during fibrosis regression. Integr. Biol. 2016, 8, 720-728. [CrossRef]

98. Dou, C.; Liu, Z.; Tu, K.; Zhang, H.; Chen, C.; Yaqoob, U.; Wang, Y.; Wen, J.; Van Deursen, J.; Sicard, D.; et al. P300 Acetyltransferase mediates stiffness-induced activation of hepatic stellate cells into tumor-promoting myofibroblasts. Gastroenterology 2018, 154, 2209-2221. [CrossRef]

99. Wang, S.; Friedman, S.L. Taming the savage breast from within: Transcription factor 21, a regulator of stellate cell deactivation. Hepatology 2020, 71, 1150-1153. [CrossRef]

100. Canbay, A.; Taimr, P.; Torok, N.; Higuchi, H.; Friedman, S.; Gores, G.J. Apoptotic body engulfment by a human stellate cell line is profibrogenic. Lab. Investig. 2003, 83, 655-663. [CrossRef]

101. Canbay, A.; Feldstein, A.E.; Higuchi, H.; Werneburg, N.; Grambihler, A.; Bronk, S.F.; Gores, G.J. Kupffer cell engulfment of apoptotic bodies stimulates death ligand and cytokine expression. Hepatology 2003, 38, 1188-1198. [CrossRef]

102. Zhan, S.S.; Jiang, J.X.; Wu, J.; Halsted, C.; Friedman, S.L.; Zern, M.A.; Torok, N.J. Phagocytosis of apoptotic bodies by hepatic stellate cells induces NADPH oxidase and is associated with liver fibrosis in vivo. Hepatology 2006, 43, 435-443. [CrossRef]

103. Kubes, P.; Mehal, W.Z. Sterile inflammation in the liver. Gastroenterology 2012, 143, 1158-1172. [CrossRef]

104. McHedlidze, T.; Waldner, M.; Zopf, S.; Walker, J.; Rankin, A.L.; Schuchmann, M.; Voehringer, D.; McKenzie, A.N.; Neurath, M.F.; Pflanz, S.; et al. Interleukin-33-dependent innate lymphoid cells mediate hepatic fibrosis. Immunity 2013, 39, 357-371. [CrossRef]

105. Seki, E.; De Minicis, S.; Osterreicher, C.H.; Kluwe, J.; Osawa, Y.; Brenner, D.A.; Schwabe, R.F. TLR4 enhances TGF-beta signaling and hepatic fibrosis. Nat. Med. 2007, 13, 1324-1332. [CrossRef]

106. Hellerbrand, C.; Jobin, C.; Licato, L.L.; Sartor, R.B.; Brenner, D.A. Cytokines induce NF-kappaB in activated but not in quiescent rat hepatic stellate cells. Am. J. Physiol. 1998, 275, G269-G278.

107. Friedman, S.L. Hepatic stellate cells: Protean, multifunctional, and enigmatic cells of the liver. Physiol. Rev. 2008, 88, 125-172. [CrossRef]

108. Koyama, Y.; Brenner, D.A. Liver inflammation and fibrosis. J. Clin. Investig. 2017, 127, 55-64. [CrossRef]

109. Tacke, F. Targeting hepatic macrophages to treat liver diseases. J. Hepatol. 2017, 66, 1300-1312. [CrossRef]

110. Marra, F.; Tacke, F. Roles for chemokines in liver disease. Gastroenterology 2014, 147, 577-594. [CrossRef]

111. Horckmans, M.; Ring, L.; Duchene, J.; Santovito, D.; Schloss, M.J.; Drechsler, M.; Weber, C.; Soehnlein, O.; Steffens, S. Neutrophils orchestrate post-myocardial infarction healing by polarizing macrophages towards a reparative phenotype. Eur. Heart J. 2017, 38, 187-197. [CrossRef]

112. Nishio, N.; Okawa, Y.; Sakurai, H.; Isobe, K. Neutrophil depletion delays wound repair in aged mice. Age 2008, 30 , 11-19. [CrossRef]

113. Cumpelik, A.; Ankli, B.; Zecher, D.; Schifferli, J.A. Neutrophil microvesicles resolve gout by inhibiting C5a-mediated priming of the inflammasome. Ann. Rheum. Dis. 2016, 75, 1236-1245. [CrossRef]

114. Calvente, C.J.; Tameda, M.; Johnson, C.D.; Del Pilar, H.; Lin, Y.C.; Adronikou, N.; Jeu, X.D.M.D.; Llorente, C.; Boyer, J.; Feldstein, A.E. Neutrophils contribute to spontaneous resolution of liver inflammation and fibrosis via microRNA-223. J. Clin. Investig. 2019, 129, 4091-4109. [CrossRef]

115. Altamirano, J.; Miquel, R.; Katoonizadeh, A.; Abraldes, J.G.; Duarte-Rojo, A.; Louvet, A.; Augustin, S.; Mookerjee, R.P.; Michelena, J.; Smyrk, T.C.; et al. A histologic scoring system for prognosis of patients with alcoholic hepatitis. Gastroenterology 2014, 146, 1231-1239. [CrossRef]

116. Gordon, S.; Taylor, P.R. Monocyte and macrophage heterogeneity. Nat. Rev. Immunol. 2005, 5, 953-964. [CrossRef]

117. MacParland, S.A.; Liu, J.C.; Ma, X.Z.; Innes, B.T.; Bartczak, A.M.; Gage, B.K.; Manuel, J.; Khuu, N.; Echeverri, J.; Linares, I.; et al. Single cell RNA sequencing of human liver reveals distinct intrahepatic macrophage populations. Nat. Commun. 2018, 9, 4383. [CrossRef]

118. Dobie, R.; Wilson-Kanamori, J.R.; Henderson, B.E.P.; Smith, J.R.; Matchett, K.P.; Portman, J.R.; Wallenborg, K.; Picelli, S.; Zagorska, A.; Pendem, S.V.; et al. Single-cell transcriptomics uncovers zonation of function in the mesenchyme during liver fibrosis. Cell Rep. 2019, 29, 1832-1847. [CrossRef]

119. Sun, Y.Y.; Li, X.F.; Meng, X.M.; Huang, C.; Zhang, L.; Li, J. Macrophage phenotype in liver injury and repair. Scand. J. Immunol. 2016, 85, 166-174. [CrossRef] [PubMed]

120. Spiller, K.L.; Wrona, E.A.; Romero-Torres, S.; Pallotta, I.; Graney, P.L.; Witherel, C.E.; Panicker, L.M.; Feldman, R.A.; Urbanska, A.M.; Santambrogio, L.; et al. Differential gene expression in human, murine, and cell line-derived macrophages upon polarization. Exp. Cell. Res. 2016, 347, 1-13. [CrossRef] [PubMed]

121. Mosser, D.M.; Edwards, J.P. Exploring the full spectrum of macrophage activation. Nat. Rev. Immunol. 2008, 8, 958-969. [CrossRef] [PubMed]

122. Roohani, S.; Tacke, F. Liver injury and the macrophage issue: Molecular and mechanistic facts and their clinical relevance. Int. J. Mol. Sci. 2021, 22, 7249. [CrossRef] [PubMed]

123. Song, P.; Zhang, J.; Zhang, Y.; Shu, Z.; Xu, P.; He, L.; Yang, C.; Wang, H.; Li, Y.; Li, Q. Hepatic recruitment of CD11b+Ly6C+ inflammatory monocytes promotes hepatic ischemia/reperfusion injury. Int. J. Mol. Med. 2017, 41, 935-945. [CrossRef] [PubMed]

124. Ramachandran, P.; Pellicoro, A.; Vernon, M.A.; Boulter, L.; Aucott, R.L.; Ali, A.; Hartland, S.N.; Snowdon, V.K.; Cappon, A.; Gordon-Walker, T.T.; et al. Differential Ly-6C expression identifies the recruited macrophage phenotype, which orchestrates the regression of murine liver fibrosis. Proc. Natl. Acad. Sci. USA 2012, 109, E3186-E3195. [CrossRef] 
125. Zimmermann, H.W.; Trautwein, C.; Tacke, F. Functional role of monocytes and macrophages for the inflammatory response in acute liver injury. Front. Physiol. 2012, 3, 56. [CrossRef]

126. Baeck, C.; Wehr, A.; Karlmark, K.R.; Heymann, F.; Vucur, M.; Gassler, N.; Huss, S.; Klussmann, S.; Eulberg, D.; Luedde, T.; et al. Pharmacological inhibition of the chemokine CCL2 (MCP-1) diminishes liver macrophage infiltration and steatohepatitis in chronic hepatic injury. Gut 2012, 61, 416-426. [CrossRef]

127. Tacke, F.; Zimmermann, H.W. Macrophage heterogeneity in liver injury and fibrosis. J. Hepatol. 2014, 60, 1090-1096. [CrossRef]

128. Yang, L.; Kwon, J.; Popov, Y.; Gajdos, G.B.; Ordog, T.; Brekken, R.A.; Mukhopadhyay, D.; Schuppan, D.; Bi, Y.; Simonetto, D.; et al. Vascular endothelial growth factor promotes fibrosis resolution and repair in mice. Gastroenterology 2014, 146, 1339-1350. [CrossRef]

129. Weng, S.Y.; Wang, X.; Vijayan, S.; Tang, Y.; Kim, Y.O.; Padberg, K.; Regen, T.; Molokanova, O.; Chen, T.; Bopp, T.; et al. IL-4 receptor alpha signaling through macrophages differentially regulates liver fibrosis progression and reversal. EBioMedicine 2018, 29, 92-103. [CrossRef]

130. Cardoso, C.C.; Matiollo, C.; Pereira, C.H.J.; Fonseca, J.S.; Alves, H.E.L.; da Silva, O.M.; Menegassi, V.D.S.; Dos Santos, C.R.; de Moraes, A.C.R.; Schiavon, L.D.L.; et al. Patterns of dendritic cell and monocyte subsets are associated with disease severity and mortality in liver cirrhosis patients. Sci. Rep. 2021, 11, 1-12. [CrossRef]

131. Lambert, C.; Sack, U. Monocytes and macrophages in flow cytometry. Cytom. Part B Clin. Cytom. 2017, 92, 178-179. [CrossRef]

132. Singanayagam, A.; Triantafyllou, E. Macrophages in chronic liver failure: Diversity, plasticity and therapeutic targeting. Front. Immunol. 2021, 12, 661182. [CrossRef]

133. Fallowfield, J.A.; Mizuno, M.; Kendall, T.J.; Constandinou, C.M.; Benyon, R.C.; Duffield, J.S.; Iredale, J.P. Scar-associated macrophages are a major source of hepatic matrix metalloproteinase-13 and facilitate the resolution of murine hepatic fibrosis. J. Immunol. 2007, 178, 5288-5295. [CrossRef]

134. Barnes, M.A.; McMullen, M.R.; Roychowdhury, S.; Madhun, N.Z.; Niese, K.; Olman, M.A.; Stavitsky, A.B.; Bucala, R.; Nagy, L.E. Macrophage migration inhibitory factor is required for recruitment of scar-associated macrophages during liver fibrosis. J. Leukoc. Biol. 2015, 97, 161-169. [CrossRef]

135. Feng, M.; Ding, J.; Wang, M.; Zhang, J.; Zhu, X.; Guan, W. Kupffer-derived matrix metalloproteinase-9 contributes to liver fibrosis resolution. Int. J. Biol. Sci. 2018, 14, 1033-1040. [CrossRef]

136. Hammel, P.; Couvelard, A.; O’Toole, D.; Ratouis, A.; Sauvanet, A.; Fléjou, J.F.; Degott, C.; Belghiti, J.; Bernades, P.; Valla, D.; et al. Regression of liver fibrosis after biliary drainage in patients with chronic pancreatitis and stenosis of the common bile duct. $N$. Engl. J. Med. 2001, 344, 418-423. [CrossRef]

137. Desmet, V.J.; Roskams, T. Cirrhosis reversal: A duel between dogma and myth. J. Hepatol. 2004, 40, 860-867. [CrossRef]

138. Dienstag, J.L.; Goldin, R.D.; Heathcote, E.J.; Hann, H.W.; Woessner, M.; Stephenson, S.L.; Gardner, S.; Gray, D.F.; Schiff, E.R. Histological outcome during long-term lamivudine therapy. Gastroenterology 2003, 124, 105-117. [CrossRef]

139. Michalopoulos, G.K.; DeFrances, M. Liver regeneration. Adv. Biochem. Eng. Biotechnol. 2005, 93, 101-134.

140. Michalopoulos, G.K.; Bhushan, B. Liver regeneration: Biological and pathological mechanisms and implications. Nat. Rev. Gastroenterol. Hepatol. 2021, 18, 40-55. [CrossRef]

141. Pellicoro, A.; Aucott, R.L.; Ramachandran, P.; Robson, A.J.; Fallowfield, J.A.; Snowdon, V.K.; Hartland, S.N.; Vernon, M.; Duffield, J.S.; Benyon, R.C.; et al. Elastin accumulation is regulated at the level of degradation by macrophage metalloelastase (MMP-12) during experimental liver fibrosis. Hepatology 2012, 55, 1965-1975. [CrossRef]

142. Wanless, I.R.; Nakashima, E.; Sherman, M. Regression of human cirrhosis. Morphologic features and the genesis of incomplete septal cirrhosis. Arch. Pathol. Lab. Med. 2000, 124, 1599-1607. [CrossRef]

143. Hsu, S.J.; Tsai, M.H.; Chang, C.C.; Hsieh, Y.H.; Huang, H.C.; Lee, F.Y.; Chuang, C.L.; Hou, M.C.; Lee, S.D. Extrahepatic angiogenesis hinders recovery of portal hypertension and collaterals in rats with cirrhosis resolution. Clin. Sci. 2018, 132, 669-683. [CrossRef]

144. Calvaruso, V.; Craxì, A. Hepatic benefits of HCV cure. J. Hepatol. 2020, 73, 1548-1556. [CrossRef]

145. Van der Meer, A.J.; Berenguer, M. Reversion of disease manifestations after HCV eradication. J. Hepatol. 2016, 65 (Suppl. 1), S95-S108. [CrossRef]

146. Martini, S.; Sacco, M.; Strona, S.; Arese, D.; Tandoi, F.; Dell Olio, D.; Stradella, D.; Cocchis, D.; Mirabella, S.; Rizza, G.; et al. Impact of viral eradication with sofosbuvir-based therapy on the outcome of post-transplant hepatitis C with severe fibrosis. Liver Int. 2016, 37, 62-70. [CrossRef]

147. Pietsch, V.; Deterding, K.; Attia, D.; Ringe, K.I.; Heidrich, B.; Cornberg, M.; Gebel, M.; Manns, M.P.; Wedemeyer, H.; Potthoff, A. Long-term changes in liver elasticity in hepatitis $C$ virus-infected patients with sustained virologic response after treatment with direct-acting antivirals. United Eur. Gastroenterol. J. 2018, 6, 1188-1198. [CrossRef]

148. Brenner, D.A. Reversibility of liver fibrosis. Gastroenterol. Hepatol. 2013, 9, 737-739.

149. Knop, V.; Hoppe, D.; Welzel, T.; Vermehren, J.; Herrmann, E.; Vermehren, A.; Friedrich-Rust, M.; Sarrazin, C.; Zeuzem, S.; Welker, M.W. Regression of fibrosis and portal hypertension in HCV-associated cirrhosis and sustained virologic response after interferon-free antiviral therapy. J. Viral Hepat. 2016, 23, 994-1002. [CrossRef]

150. Mandorfer, M.; Kozbial, K.; Schwabl, P.; Freissmuth, C.; Schwarzer, R.; Stern, R.; Chromy, D.; Stättermayer, A.F.; Reiberger, T.; Beinhardt, S.; et al. Sustained virologic response to interferon-free therapies ameliorates HCV-induced portal hypertension. J. Hepatol. 2016, 65, 692-699. [CrossRef] 
151. Fontana, R.J.; Hann, H.W.; Perrillo, R.P.; Vierling, J.M.; Wright, T.; Rakela, J.; Anschuetz, G.; Davis, R.; Gardner, S.D.; Brown, N.A. Determinants of early mortality in patients with decompensated chronic hepatitis B treated with antiviral therapy. Gastroenterology 2002, 123, 719-727. [CrossRef] [PubMed]

152. Vanlemmens, C.; Di Martino, V.; Milan, C.; Messner, M.; Minello, A.; Duvoux, C.; Poynard, T.; Perarnau, J.M.; Piquet, M.A.; Pageaux, G.P.; et al. Immediate listing for liver transplantation versus standard care for Child-Pugh stage B alcoholic cirrhosis: A randomized trial. Ann. Intern. Med. 2009, 150, 153-161. [CrossRef] [PubMed]

153. Vinaixa, C.; Strasser, S.I.; Berenguer, M. Disease reversibility in patients with post-hepatitis C cirrhosis: Is the point of no return the same before and after liver transplantation? A review. Transplantation 2017, 101, 916-923. [CrossRef] [PubMed]

154. Fattovich, G.; Stroffolini, T.; Zagni, I.; Donato, F. Hepatocellular carcinoma in cirrhosis: Incidence and risk factors. Gastroenterology 2004, 127 (Suppl. 1), S35-S50. [CrossRef]

155. O'Rourke, J.M.; Sagar, V.M.; Shah, T.; Shetty, S. Carcinogenesis on the background of liver fibrosis: Implications for the management of hepatocellular cancer. World J. Gastroenterol. 2018, 24, 4436-4447. [CrossRef]

156. Affo, S.; Yu, L.X.; Schwabe, R.F. The role of cancer-associated fibroblasts and fibrosis in liver cancer. Annu. Rev. Pathol. 2017, 12, 153-186. [CrossRef]

157. Baglieri, J.; Brenner, D.A.; Kisseleva, T. The role of fibrosis and liver-associated fibroblasts in the pathogenesis of hepatocellular carcinoma. Int. J. Mol. Sci. 2019, 20, 1723. [CrossRef]

158. Rutledge, S.M.; Zheng, H.; Li, D.K.; Chung, R.T. No evidence for higher rates of hepatocellular carcinoma after direct-acting antiviral treatment: A meta-analysis. Hepatoma Res. 2019, 5, 1-12. [CrossRef]

159. Ghany, M.G.; Morgan, T.R.; Panel, A.H.C. G Hepatitis C Guidance 2019 Update: American Association for the Study of Liver Diseases-Infectious Diseases Society of America Recommendations for Testing, Managing, and Treating Hepatitis C Virus Infection. Hepatology 2019, 71, 686-721. [CrossRef]

160. Faillaci, F.; Marzi, L.; Critelli, R.; Milosa, F.; Schepis, F.; Turola, E.; Andreani, S.; Vandelli, G.; Bernabucci, V.; Lei, B.; et al. Liver angiopoietin-2 is a key predictor of de novo or recurrent hepatocellular cancer after hepatitis $\mathrm{C}$ virus direct-acting antivirals. Hepatology 2018, 68, 1010-1024. [CrossRef]

161. Nahon, P.; Layese, R.; Bourcier, V.; Cagnot, C.; Marcellin, P.; Guyader, D.; Pol, S.; Larrey, D.; De Lédinghen, V.; Ouzan, D.; et al. Incidence of hepatocellular carcinoma after direct antiviral therapy for $\mathrm{HCV}$ in patients with cirrhosis included in surveillance programs. Gastroenterology 2018, 155, 1436-1450. [CrossRef]

162. Villani, R.; Facciorusso, A.; Bellanti, F.; Tamborra, R.; Piscazzi, A.; Landriscina, M.; Vendemiale, G.; Serviddio, G. DAAs rapidly reduce inflammation but increase serum VEGF level: A rationale for tumor risk during anti-HCV treatment. PLoS ONE 2016, 11, e0167934. [CrossRef]

163. Gardini, A.C.; Foschi, F.G.; Conti, F.; Petracci, E.; Vukotic, R.; Marisi, G.; Buonfiglioli, F.; Vitale, G.; Ravaioli, F.; Gitto, S.; et al. Immune inflammation indicators and ALBI score to predict liver cancer in HCV-patients treated with direct-acting antivirals. Dig. Liver Dis. 2019, 51, 681-688. [CrossRef]

164. Kantari-Mimoun, C.; Castells, M.; Klose, R.; Meinecke, A.K.; Lemberger, U.J.; Rautou, P.E.; Pinot-Roussel, H.; Badoual, C.; Schrödter, K.; Österreicher, C.H.; et al. Resolution of liver fibrosis requires myeloid cell-driven sinusoidal angiogenesis. Hepatology 2015, 61, 2042-2055. [CrossRef]

165. Xie, G.; Wang, X.; Wang, L.; Atkinson, R.D.; Kanel, G.C.; Gaarde, W.A.; Deleve, L.D. Role of differentiation of liver sinusoidal endothelial cells in progression and regression of hepatic fibrosis in rats. Gastroenterology 2012, 142, 918-927. [CrossRef]

166. Beaven, S.W.; Wroblewski, K.; Wang, J.; Hong, C.; Bensinger, S.; Tsukamoto, H.; Tontonoz, P. Liver X receptor signaling is a determinant of stellate cell activation and susceptibility to fibrotic liver disease. Gastroenterology 2011, 140, 1052-1062. [CrossRef]

167. Wang, Y.Y.; Dahle, M.K.; Agren, J.; Myhre, A.E.; Reinholt, F.P.; Foster, S.J.; Collins, J.L.; Thiemermann, C.; Aasen, A.O.; Wang, J.E. Activation of the liver $\mathrm{X}$ receptor protects against hepatic injury in endotoxemia by suppressing Kupffer cell activation. Shock 2006, 25, 141-146. [CrossRef]

168. Königshofer, P.; Brusilovskaya, K.; Petrenko, O.; Hofer, B.S.; Schwabl, P.; Trauner, M.; Reiberger, T. Nuclear receptors in liver fibrosis. Biochim. Biophys. Acta Mol. Basis Dis. 2021, 1867, 166235. [CrossRef]

169. Xing, Y.; Zhao, T.; Gao, X.; Wu, Y. Liver X receptor $\alpha$ is essential for the capillarization of liver sinusoidal endothelial cells in liver injury. Sci. Rep. 2016, 6, 21309. [CrossRef]

170. Lee, H.S.; Choi, J.; Son, T.; Wee, H.J.; Bae, S.J.; Seo, J.H.; Park, J.H.; Ryu, S.H.; Lee, D.; Jang, M.K.; et al. Altered AKAP12 expression in portal fibroblasts and liver sinusoids mediates transition from hepatic fibrogenesis to fibrosis resolution. Exp. Mol. Med. 2018, 50,1-13. [CrossRef]

171. Xu, M.; Xu, H.H.; Lin, Y.; Sun, X.; Wang, L.J.; Fang, Z.P.; Su, X.H.; Liang, X.J.; Hu, Y.; Liu, Z.M.; et al. LECT2, a ligand for Tie1, plays a crucial role in liver fibrogenesis. Cell 2019, 178, 1478-1492. [CrossRef]

172. Lee, Y.A.; Friedman, S.L. Reversal, maintenance or progression: What happens to the liver after a virologic cure of hepatitis C? Antivir. Res. 2014, 107, 23-30. [CrossRef]

173. Jung, Y.K.; Yim, H.J. Reversal of liver cirrhosis: Current evidence and expectations. Korean J. Intern. Med. 2017, 32, $213-228$. [CrossRef]

174. Lackner, C.; Tiniakos, D. Fibrosis and alcohol-related liver disease. J. Hepatol. 2019, 70, 294-304. [CrossRef] [PubMed] 
175. Ikenaga, N.; Peng, Z.W.; Vaid, K.A.; Liu, S.B.; Yoshida, S.; Sverdlov, D.Y.; Mikels-Vigdal, A.; Smith, V.; Schuppan, D.; Popov, Y.V. Selective targeting of lysyl oxidase-like 2 (LOXL2) suppresses hepatic fibrosis progression and accelerates its reversal. Gut 2017, 66, 1697-1708. [CrossRef] [PubMed]

176. Harrison, S.A.; Abdelmalek, M.F.; Caldwell, S.; Shiffman, M.L.; Diehl, A.M.; Ghalib, R.; Lawitz, E.J.; Rockey, D.C.; Schall, R.A.; Jia, C.; et al. Simtuzumab is ineffective for patients with bridging fibrosis or compensated cirrhosis caused by nonalcoholic steatohepatitis. Gastroenterology 2018, 155, 1140-1153. [CrossRef] [PubMed]

177. Fickert, P. Is this the last requiem for simtuzumab? Hepatology 2019, 69, 476-479. [CrossRef] [PubMed]

178. Sato, Y.; Murase, K.; Kato, J.; Kobune, M.; Sato, T.; Kawano, Y.; Takimoto, R.; Takada, K.; Miyanishi, K.; Matsunaga, T.; et al. Resolution of liver cirrhosis using vitamin A-coupled liposomes to deliver siRNA against a collagen-specific chaperone. Nat. Biotechnol. 2008, 26, 431-442. [CrossRef]

179. Piaz, V.D.; Giovannoni, M.P. Phosphodiesterase 4 inhibitors, structurally unrelated to rolipram, as promising agents for the treatment of asthma and other pathologies. Eur. J. Med. Chem. 2000, 35, 463-480. [CrossRef]

180. Stumm, C.L.; Wettlaufer, S.H.; Jancar, S.; Peters-Golden, M. Airway remodeling in murine asthma correlates with a defect in PGE2 synthesis by lung fibroblasts. Am. J. Physiol. Cell. Mol. Physiol. 2011, 301, L636-L644. [CrossRef]

181. Insel, P.A.; Murray, F.; Yokoyama, U.; Romano, S.; Yun, H.; Brown, L.; Snead, A.; Lu, D.; Aroonsakool, N. cAMP and Epac in the regulation of tissue fibrosis. Br. J. Pharmacol. 2012, 166, 447-456. [CrossRef]

182. Shattil, S.J.; Kashiwagi, H.; Pampori, N. Integrin signaling: The platelet paradigm. Blood 1998, 91, 2645-2657. [CrossRef]

183. Beebe, H.G.; Dawson, D.L.; Cutler, B.S.; Herd, J.A.; Strandness, D.E.; Bortey, E.B.; Forbes, W.P. A new pharmacological treatment for intermittent claudication: Results of a randomized, multicenter trial. Arch. Intern. Med. 1999, 159, 2041-2050. [CrossRef]

184. Pearce, L.; Ghosh, J.; Counsell, A.; Serracino-Inglott, F. Cilostazol and peripheral arterial disease. Expert Opin. Pharmacother. 2008, 9, 2683-2690. [CrossRef]

185. Colman, R.W. Platelet cyclic adenosine monophosphate phosphodiesterases: Targets for regulating platelet-related thrombosis. Semin. Thromb. Hemost. 2004, 30, 451-460. [CrossRef]

186. Elam, M.B.; Heckman, J.; Crouse, J.R.; Hunninghake, D.B.; Herd, J.A.; Davidson, M.; Gordon, I.L.; Bortey, E.B.; Forbes, W.P. Effect of the novel antiplatelet agent cilostazol on plasma lipoproteins in patients with intermittent claudication. Arter. Thromb. Vasc. Biol. 1998, 18, 1942-1947. [CrossRef]

187. Chancharoenthana, W.; Leelahavanichkul, A.; Taratummarat, S.; Wongphom, J.; Tiranathanagul, K.; Eiam-Ong, S. Cilostazol attenuates intimal hyperplasia in a mouse model of chronic kidney disease. PLoS ONE 2017, 12, e0187872. [CrossRef]

188. Kherallah, R.Y.; Khawaja, M.; Olson, M.; Angiolillo, D.; Birnbaum, Y. Cilostazol: A review of basic mechanisms and clinical uses. Cardiovasc. Drugs Ther. 2021. [CrossRef]

189. Fujita, K.; Nozaki, Y.; Wada, K.; Yoneda, M.; Endo, H.; Takahashi, H.; Iwasaki, T.; Inamori, M.; Abe, Y.; Kobayashi, N.; et al. Effectiveness of antiplatelet drugs against experimental non-alcoholic fatty liver disease. Gut 2008, 57, 1583-1591. [CrossRef]

190. Saito, S.; Hata, K.; Iwaisako, K.; Yanagida, A.; Takeiri, M.; Tanaka, H.; Kageyama, S.; Hirao, H.; Ikeda, K.; Asagiri, M.; et al. Cilostazol attenuates hepatic stellate cell activation and protects mice against carbon tetrachloride-induced liver fibrosis. Hepatol. Res. 2013, 44, 460-473. [CrossRef]

191. El Awdan, S.A.; Rahman, R.F.A.; Ibrahim, H.M.; Hegazy, R.R.; El Marasy, S.A.; Badawi, M.; Arbid, M.S. Regression of fibrosis by cilostazol in a rat model of thioacetamide-induced liver fibrosis: Up regulation of hepatic cAMP, and modulation of inflammatory, oxidative stress and apoptotic biomarkers. PLoS ONE 2019, 14, e0216301. [CrossRef]

192. Han, K.; Zhang, Y.; Yang, Z. Cilostazol protects rats against alcohol-induced hepatic fibrosis via suppression of TGF- $\beta 1 / C T G F$ activation and the cAMP/Epac1 pathway. Exp. Ther. Med. 2019, 17, 2381-2388. [CrossRef]

193. Packer, M.; Carver, J.R.; Rodeheffer, R.J.; Ivanhoe, R.J.; DiBianco, R.; Zeldis, S.M.; Hendrix, G.H.; Bommer, W.J.; Elkayam, U.; Kukin, M.L.; et al. Effect of oral milrinone on mortality in severe chronic heart failure. N. Engl. J. Med. 1991, 325, 1468-1475. [CrossRef]

194. Bangalore, S.; Singh, A.; Toklu, B.; DiNicolantonio, J.J.; Croce, K.; Feit, F.; Bhatt, D.L. Efficacy of cilostazol on platelet reactivity and cardiovascular outcomes in patients undergoing percutaneous coronary intervention: Insights from a meta-analysis of randomised trials. Open Heart 2014, 1, e000068. [CrossRef]

195. Umazume, T.; Funabashi, N.; Inoue, T.; Nishi, T.; Shimizu, T.; Jo, K.; Ishikawa, T.; Nakamura, Y.; Miyazaki, A.; Kobayashi, Y. Adverse effects of cilostazol on left ventricular function in a patient with a sigmoid shaped interventricular septum. Int. J. Cardiol. 2013, 165, 551-555. [CrossRef]

196. Marrone, G.; Shah, V.H.; Gracia-Sancho, J. Sinusoidal communication in liver fibrosis and regeneration. J. Hepatol. 2016, 65, 608-617. [CrossRef]

197. Paizis, G.; Gilbert, R.E.; Cooper, M.E.; Murthi, P.; Schembri, J.M.; Wu, L.L.; Rumble, J.R.; Kelly, D.J.; Tikellis, C.; Cox, A.; et al. Effect of angiotensin II type 1 receptor blockade on experimental hepatic fibrogenesis. J. Hepatol. 2001, 35, 376-385. [CrossRef]

198. Bataller, R.; Sancho-Bru, P.; Ginès, P.; Lora, J.M.; Al-Garawi, A.; Solé, M.; Colmenero, J.; Nicolás, J.M.; Jiménez, W.; Weich, N.; et al. Activated human hepatic stellate cells express the renin-angiotensin system and synthesize angiotensin II. Gastroenterology 2003, 125, 117-125. [CrossRef]

199. Zhu, Q.; Li, N.; Li, F.; Zhou, Z.; Han, Q.; Lv, Y.; Sang, J.; Liu, Z. Therapeutic effect of renin angiotensin system inhibitors on liver fibrosis. J. Renin Angiotensin Aldosterone Syst. 2016, 17, 1470320316628717. [CrossRef] 
200. Berg, T.; DeLanghe, S.; Al Alam, D.; Utley, S.; Estrada, J.; Wang, K.S. $\beta$-catenin regulates mesenchymal progenitor cell differentiation during hepatogenesis. J. Surg. Res. 2010, 164, 276-285. [CrossRef]

201. Cheng, J.H.; She, H.; Han, Y.P.; Wang, J.; Xiong, S.; Asahina, K.; Tsukamoto, H. Wnt antagonism inhibits hepatic stellate cell activation and liver fibrosis. Am. J. Physiol. Liver Physiol. 2008, 294, G39-G49. [CrossRef] [PubMed]

202. Kordes, C.; Sawitza, I.; Häussinger, D. Canonical Wnt signaling maintains the quiescent stage of hepatic stellate cells. Biochem. Biophys. Res. Commun. 2008, 367, 116-123. [CrossRef] [PubMed]

203. Tokunaga, Y.; Osawa, Y.; Ohtsuki, T.; Hayashi, Y.; Yamaji, K.; Yamane, D.; Hara, M.; Munekata, K.; Tsukiyama-Kohara, K.; Hishima, T.; et al. Selective inhibitor of Wnt/ $\beta$-catenin/CBP signaling ameliorates hepatitis $\mathrm{C}$ virus-induced liver fibrosis in mouse model. Sci. Rep. 2017, 7, 325. [CrossRef] [PubMed]

204. Osawa, Y.; Kojika, E.; Hayashi, Y.; Kimura, M.; Nishikawa, K.; Yoshio, S.; Doi, H.; Kanto, T.; Kimura, K. Tumor necrosis factor- $\alpha$-mediated hepatocyte apoptosis stimulates fibrosis in the steatotic liver in mice. Hepatol. Commun. 2018, 2, 407-420. [CrossRef] [PubMed]

205. Jiang, L.; Zhang, H.; Xiao, D.; Wei, H.; Chen, Y. Farnesoid X receptor (FXR): Structures and ligands. Comput. Struct. Biotechnol. J. 2021, 19, 2148-2159. [CrossRef]

206. Modica, S.; Moschetta, A. Nuclear bile acid receptor FXR as pharmacological target: Are we there yet? FEBS Lett. 2006, 580, 5492-5499. [CrossRef]

207. Pastore, M.; Marra, F. Liver fibrosis in the context of nonalcoholic steatohepatitis: The role of adipokines. Minerva Gastroenterol. Dietol. 2018, 64, 39-50.

208. Fiorucci, S.; Antonelli, E.; Rizzo, G.; Renga, B.; Mencarelli, A.; Riccardi, L.; Orlandi, S.; Pellicciari, R.; Morelli, A. The nuclear receptor SHP mediates inhibition of hepatic stellate cells by FXR and protects against liver fibrosis. Gastroenterology 2004, 127, 1497-1512. [CrossRef]

209. Modica, S.; Gadaleta, R.M.; Moschetta, A. Deciphering the nuclear bile acid receptor FXR paradigm. Nucl. Recept. Signal. 2010, 8, e005. [CrossRef]

210. Wang, Y.D.; Chen, W.D.; Wang, M.; Yu, D.; Forman, B.M.; Huang, W. Farnesoid X receptor antagonizes nuclear factor kappaB in hepatic inflammatory response. Hepatology 2008, 48, 1632-1643. [CrossRef]

211. Neuschwander-Tetri, B.A.; Loomba, R.; Sanyal, A.J.; Lavine, J.E.; Van Natta, M.L.; Abdelmalek, M.F.; Chalasani, N.; Dasarathy, S.; Diehl, A.M.; Hameed, B.; et al. Farnesoid X nuclear receptor ligand obeticholic acid for non-cirrhotic, non-alcoholic steatohepatitis (FLINT): A multicentre, randomised, placebo-controlled trial. Lancet 2015, 385, 956-965. [CrossRef]

212. Younossi, Z.M.; Ratziu, V.; Loomba, R.; Rinella, M.; Anstee, Q.M.; Goodman, Z.; Bedossa, P.; Geier, A.; Beckebaum, S.; Newsome, P.N.; et al. Obeticholic acid for the treatment of non-alcoholic steatohepatitis: Interim analysis from a multicentre, randomised, placebo-controlled phase 3 trial. Lancet 2019, 394, 2184-2196. [CrossRef]

213. Schwabe, R.F.; Luedde, T. Apoptosis and necroptosis in the liver: A matter of life and death. Nat. Rev. Gastroenterol. Hepatol. 2018, 15, 738-752. [CrossRef]

214. Gracia-Sancho, J.; Manicardi, N.; Ortega-Ribera, M.; Maeso-Díaz, R.; Guixé-Muntet, S.; Fernández-Iglesias, A.; Hide, D.; GarcíaCalderó, H.; Boyer-Díaz, Z.; Contreras, P.C.; et al. Emricasan ameliorates portal hypertension and liver fibrosis in cirrhotic rats through a hepatocyte-mediated paracrine mechanism. Hepatol. Commun. 2019, 3, 987-1000. [CrossRef]

215. Harrison, S.A.; Goodman, Z.; Jabbar, A.; Vemulapalli, R.; Younes, Z.H.; Freilich, B.; Sheikh, M.Y.; Schattenberg, J.M.; Kayali, Z.; Zivony, A.; et al. A randomized, placebo-controlled trial of emricasan in patients with NASH and F1-F3 fibrosis. J. Hepatol. 2020, 72, 816-827. [CrossRef]

216. Garcia-Tsao, G.; Bosch, J.; Kayali, Z.; Harrison, S.A.; Abdelmalek, M.F.; Lawitz, E.; Satapathy, S.K.; Ghabril, M.; Shiffman, M.L.; Younes, Z.H.; et al. Randomized placebo-controlled trial of emricasan for non-alcoholic steatohepatitis-related cirrhosis with severe portal hypertension. J. Hepatol. 2020, 72, 885-895. [CrossRef]

217. Yoon, Y.C.; Fang, Z.; Lee, J.E.; Park, J.H.; Ryu, J.K.; Jung, K.H.; Hong, S.S. Selonsertib inhibits liver fibrosis via downregulation of ASK1/ MAPK pathway of hepatic stellate cells. Biomol. Ther. 2020, 28, 527-536. [CrossRef]

218. Loomba, R.; Lawitz, E.; Mantry, P.S.; Jayakumar, S.; Caldwell, S.H.; Arnold, H.; Diehl, A.M.; Djedjos, C.S.; Han, L.; Myers, R.P.; et al. The ASK1 inhibitor selonsertib in patients with nonalcoholic steatohepatitis: A randomized, phase 2 trial. Hepatology 2018, 67, 549-559. [CrossRef]

219. Harrison, S.A.; Wong, V.W.; Okanoue, T.; Bzowej, N.; Vuppalanchi, R.; Younes, Z.; Kohli, A.; Sarin, S.; Caldwell, S.H.; Alkhouri, N.; et al. Selonsertib for patients with bridging fibrosis or compensated cirrhosis due to NASH: Results from randomized phase III STELLAR trials. J. Hepatol. 2020, 73, 26-39. [CrossRef]

220. Van der Heide, D.; Weiskirchen, R.; Bansal, R. Therapeutic targeting of hepatic macrophages for the treatment of liver diseases. Front. Immunol. 2019, 10, 2852. [CrossRef]

221. Guo, Y.C.; Lu, L.G. Antihepatic fibrosis drugs in clinical trials. J. Clin. Transl. Hepatol. 2020, 8, 304-312. [CrossRef]

222. Traber, P.G.; Chou, H.; Zomer, E.; Hong, F.; Klyosov, A.; Fiel, M.I.; Friedman, S.L. Regression of fibrosis and reversal of cirrhosis in rats by galectin inhibitors in thioacetamide-induced liver disease. PLoS ONE 2013, 8, e75361. [CrossRef]

223. Harrison, S.A.; Marri, S.R.; Chalasani, N.; Kohli, R.; Aronstein, W.; Thompson, G.A.; Irish, W.; Miles, M.V.; Xanthakos, S.A.; Lawitz, E.; et al. Randomised clinical study: GR-MD-02, a galectin-3 inhibitor, vs. placebo in patients having non-alcoholic steatohepatitis with advanced fibrosis. Aliment. Pharmacol. Ther. 2016, 44, 1183-1198. [CrossRef] 
224. Chalasani, N.; Abdelmalek, M.F.; Garcia-Tsao, G.; Vuppalanchi, R.; Alkhouri, N.; Rinella, M.; Noureddin, M.; Pyko, M.; Shiffman, M.; Sanyal, A.; et al. Effects of belapectin, an inhibitor of galectin-3, in patients with nonalcoholic steatohepatitis with cirrhosis and portal hypertension. Gastroenterology 2020, 158, 1334-1345. [CrossRef]

225. Triantafyllou, E.; Woollard, K.J.; McPhail, M.J.W.; Antoniades, C.G.; Possamai, L.A. The role of monocytes and macrophages in acute and acute-on-chronic liver failure. Front. Immunol. 2018, 9, 2948. [CrossRef]

226. Colino, C.I.; Lanao, J.M.; Gutierrez-Millan, C. Targeting of hepatic macrophages by therapeutic nanoparticles. Front. Immunol. 2020, 11, 218. [CrossRef]

227. Chen, L.; Brenner, D.A.; Kisseleva, T. Combatting fibrosis: Exosome-based therapies in the regression of liver fibrosis. Hepatol. Commun. 2018, 3, 180-192. [CrossRef]

228. Borges, F.T.; Melo, S.A.; Özdemir, B.C.; Kato, N.; Revuelta, I.; Miller, C.A.; Gattone, V.H.; LeBleu, V.S.; Kalluri, R. TGF- $\beta 1-$ containing exosomes from injured epithelial cells activate fibroblasts to initiate tissue regenerative responses and fibrosis. J. Am. Soc. Nephrol. 2013, 24, 385-392. [CrossRef]

229. De Jong, O.G.; Van Balkom, B.W.; Gremmels, H.; Verhaar, M.C. Exosomes from hypoxic endothelial cells have increased collagen crosslinking activity through up-regulation of lysyl oxidase-like 2. J. Cell. Mol. Med. 2016, 20, 342-350. [CrossRef]

230. Charrier, A.; Chen, R.; Chen, L.; Kemper, S.; Hattori, T.; Takigawa, M.; Brigstock, D.R. Exosomes mediate intercellular transfer of pro-fibrogenic connective tissue growth factor (CCN2) between hepatic stellate cells, the principal fibrotic cells in the liver. Surgery 2014, 156, 548-555. [CrossRef]

231. Alhomrani, M.; Correia, J.; Zavou, M.; Leaw, B.; Kuk, N.; Xu, R.; Saad, M.I.; Hodge, A.; Greening, D.W.; Lim, R.; et al. The human amnion epithelial cell secretome decreases hepatic fibrosis in mice with chronic liver fibrosis. Front. Pharmacol. 2017, 8, 748. [CrossRef] [PubMed]

232. Hyun, J.; Wang, S.; Kim, J.; Kim, G.J.; Jung, Y. MicroRNA125b-mediated Hedgehog signaling influences liver regeneration by chorionic plate-derived mesenchymal stem cells. Sci. Rep. 2015, 5, 14135. [CrossRef] [PubMed]

233. Li, J.; Ghazwani, M.; Zhang, Y.; Lu, J.; Fan, J.; Gandhi, C.R.; Li, S. miR-122 regulates collagen production via targeting hepatic stellate cells and suppressing P4HA1 expression. J. Hepatol. 2013, 58, 522-528. [CrossRef] [PubMed]

234. Lou, G.; Chen, Z.; Zheng, M.; Liu, Y. Mesenchymal stem cell-derived exosomes as a new therapeutic strategy for liver diseases. Exp. Mol. Med. 2017, 49, e346. [CrossRef] [PubMed]

235. Hu, C.; Zhao, L.; Duan, J.; Li, L. Strategies to improve the efficiency of mesenchymal stem cell transplantation for reversal of liver fibrosis. J. Cell. Mol. Med. 2019, 23, 1657-1670. [CrossRef] [PubMed]

236. Park, M.; Kim, Y.H.; Woo, S.Y.; Lee, H.J.; Yu, Y.; Kim, H.S.; Park, Y.S.; Jo, I.; Park, J.W.; Jung, S.C.; et al. Tonsil-derived mesenchymal stem cells ameliorate CCl4-induced liver fibrosis in mice via autophagy activation. Sci. Rep. 2015, 5, 8616. [CrossRef] [PubMed]

237. Zhang, G.Z.; Sun, H.C.; Zheng, L.B.; Guo, J.B.; Zhang, X.L. In vivo hepatic differentiation potential of human umbilical cordderived mesenchymal stem cells: Therapeutic effect on liver fibrosis/cirrhosis. World J. Gastroenterol. 2017, 23, 8152-8168. [CrossRef]

238. Pinheiro, D.; Dias, I.; Ribeiro Silva, K.; Stumbo, A.C.; Thole, A.; Cortez, E.; De Carvalho, L.; Weiskirchen, R.; Carvalho, S. Mechanisms underlying cell therapy in liver fibrosis: An overview. Cells 2019, 8, 1339. [CrossRef]

239. Xu, L.; Gong, Y.; Wang, B.; Shi, K.; Hou, Y.; Wang, L.; Lin, Z.; Han, Y.; Lu, L.; Chen, D.; et al. Randomized trial of autologous bone marrow mesenchymal stem cells transplantation for hepatitis B virus cirrhosis: Regulation of Treg/Th17 cells. J. Gastroenterol. Hepatol. 2014, 29, 1620-1628. [CrossRef]

240. Zhang, Z.; Lin, H.; Shi, M.; Xu, R.; Fu, J.; Lv, J.; Chen, L.; Lv, S.; Li, Y.; Yu, S.; et al. Human umbilical cord mesenchymal stem cells improve liver function and ascites in decompensated liver cirrhosis patients. J. Gastroenterol. Hepatol. 2012, 27 (Suppl. 2), 112-120. [CrossRef]

241. Fang, X.; Liu, L.; Dong, J.; Zhang, J.; Song, H.; Song, Y.; Huang, Y.; Cui, X.; Lin, J.; Chen, C.; et al. A study about immunomodulatory effect and efficacy and prognosis of human umbilical cord mesenchymal stem cells in patients with chronic hepatitis B-induced decompensated liver cirrhosis. J. Gastroenterol. Hepatol. 2018, 33, 774-780. [CrossRef]

242. Suk, K.T.; Yoon, J.H.; Kim, M.Y.; Kim, C.W.; Kim, J.K.; Park, H.; Hwang, S.G.; Kim, D.J.; Lee, B.S.; Lee, S.H.; et al. Transplantation with autologous bone marrow-derived mesenchymal stem cells for alcoholic cirrhosis: Phase 2 trial. Hepatology 2016, 64, 2185-2197. [CrossRef]

243. Schwabe, R.F.; Bataller, R.; Brenner, D.A. Human hepatic stellate cells express CCR5 and RANTES to induce proliferation and migration. Am. J. Physiol. Liver Physiol. 2003, 285, G949-G958. [CrossRef]

244. Seki, E.; De Minicis, S.; Gwak, G.Y.; Kluwe, J.; Inokuchi, S.; Bursill, C.A.; Llovet, J.M.; Brenner, D.A.; Schwabe, R.F. CCR1 and CCR5 promote hepatic fibrosis in mice. J. Clin. Investig. 2009, 119, 1858-1870. [CrossRef]

245. Lefebvre, E.; Moyle, G.; Reshef, R.; Richman, L.P.; Thompson, M.; Hong, F.; Chou, H.L.; Hashiguchi, T.; Plato, C.; Poulin, D.; et al. Antifibrotic effects of the dual CCR2/CCR5 antagonist cenicriviroc in animal models of liver and kidney fibrosis. PLoS ONE 2016, 11, e0158156. [CrossRef]

246. Friedman, S.L.; Ratziu, V.; Harrison, S.A.; Abdelmalek, M.F.; Aithal, G.P.; Caballeria, J.; Francque, S.; Farrell, G.; Kowdley, K.V.; Craxi, A.; et al. A randomized, placebo-controlled trial of cenicriviroc for treatment of nonalcoholic steatohepatitis with fibrosis. Hepatology 2018, 67, 1754-1767. [CrossRef] 